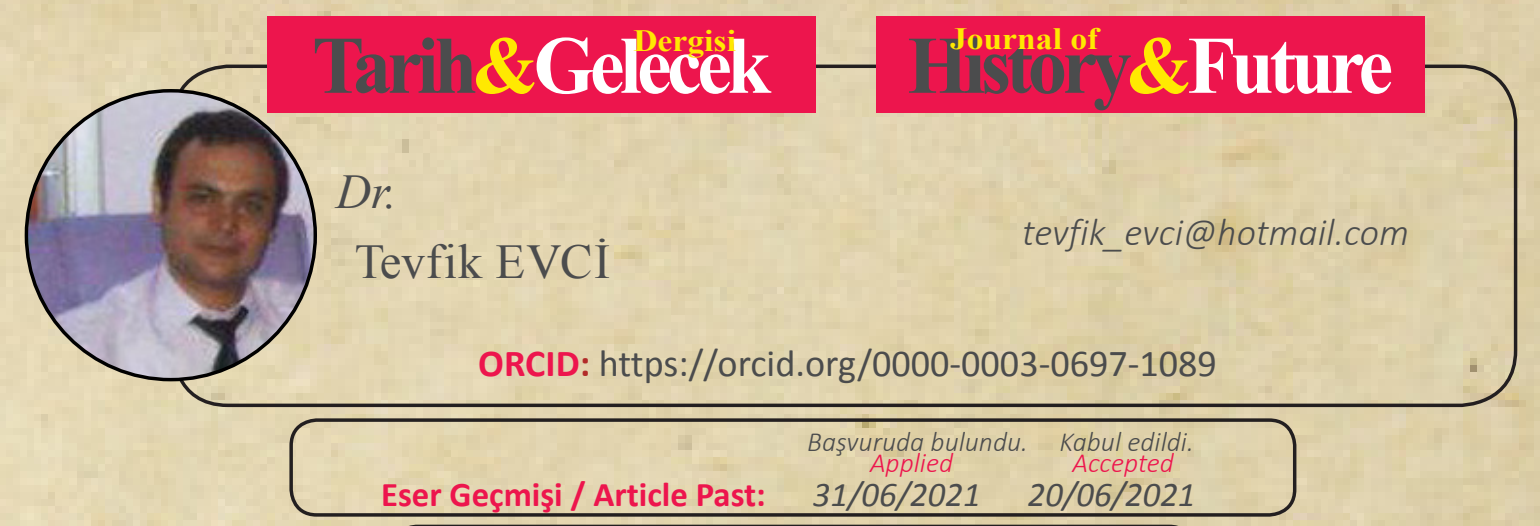

Araştırma Makalesi

DOI: http://dx.doi.org/10.21551/jhf.945981

Research Paper

Indexed by

ERIHPORNAS

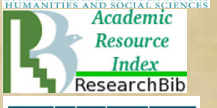

R]ISA $\mathbf{I}$

Orjinal Makale / Orginal Paper

\title{
Osmanlı Taşra İdaresinde Reform: Kastamonu Örneğinde Eyaletten Vilayete Geçiş ve Vilayet Umûm Meclisleri
}

\section{Reform in the Ottoman Provincial Administration: The Transition from State to Province and Provincial General Assemblies in the Case of Kastamonu}

\section{$\ddot{O} \mathbf{z}$}

Tanzimat Fermanı ile Osmanlı İmparatorluğu’nda idarî, askerî, malî vb. daha birçok alanda düzenlemeler yapılmıştı. Osmanlı idarecileri kötü gidişatı durdurabilmek için özellikle III. Selim devrinden beri Batı modelinde birtakım düzenlemeleri hayata geçirmişlerdi. İşte, 1839 yılında ilan edilen ve Gülhane Hatt-1 Hümayunu olarak da anılan ferman, bu düzenlemelerin adeta zirvesidir. Günümüzde dahi gerek ferman gerekse fermanın uygulanması sosyal bilimciler arasında tartışılmaya devam etmektedir. Kimileri uygulamaları ülke gerçeklerinden uzak "aşırı batıcı" olarak tenkit ederken kimleri ise imparatorluğun çöküşünün engellenebilmesi için "zorunluluk" olarak desteklemektedir fakat şunu belirtmek gerekir ki reformlar, neredeyse İmparatorluğun siyasi ömrünün sonuna kadar yoğunluğu değişse de yapılmaya devam edilmiştir.

Bu reformlardan birisi de idare alanındaydı. 1864 tarihinde yürürlüğe giren bir nizamname, İmparatorluğun taşra idaresinde yeni bir dönemi işaret ediyordu. Taşra idaresinde uzun süredir uygulanan eyalet sisteminden vazgeçilerek vilayet sistemine geçilmişti. Çalışma konumuz olan Kastamonu da bu yerlerden birisiydi. Yeni nizam ile birlikte yeni idari birimler teşkil edilmişti. Bir başka yenilik de vilayet merkezlerinde valinin başkanlığında, vilayete bağlı livalardan (sancaklardan) seçimle gelen üyelerden oluşan Vilayet Umûmi Meclisi'dir. Azalar; bayındırlık, vilayette tarımın ve ticaretin geliştirilmesi gibi konularda kendi bölgelerinin ihtiyaçlarını ve taleplerini dilekçelerle valiye sunuyorlardı. Mecliste tartışılarak alınan kararlar ile talepler, Şûrâ-yı Devlet'e gönderiliyor ve burada uygun görülenlere onay veriliyordu. Kastamonu'da vilayet sistemine geçişle birlikte yeni nizam tesis edilmiş ve livalarda yapılan seçimle belirlenen üyeler, meclis-i umumiye gelerek 
çalışmaya başlamışlardı. Meclis, kendisine verilen görevi yerine getirmiş, Kastamonu Vilayeti’ne bağlı kazaların taleplerini müzakere etmiş ve bunları merkezi idareye bildirmişti. Bu çalışmamızda, Kastamonu Vilayeti'nin kurulmasını ve yine bu yeni sistemin bir kurumu olan umumi meclisin çalışma şekli, çeşitli örneklerle anlatılmaya çalışılmıştır. Böylece, yeni taşra idare sisteminin vilayetteki uygulaması ile bunların olumlu ya da olumsuz neticelerinin daha iyi görüleceği kanaatindeyiz. Öte yandan dönemin Kastamonu vilayeti ve mülhak kazaların sorunlarına ve taleplerine dair verilen örneklerin, Kastamonu yerel tarih çalışmalarına katkı sağlayacağı da ümit edilmektedir.

\section{Anahtar Kelimeler: Kastamonu, Meclis-i Umûmi, Taşra İdaresi}

\section{Abstract}

After the Imperial Rescript of Gülhane (Tanzimat Fermanı), regulations have been made in Ottoman Empire in several areas including administrative, military, financial and many other domains. In order to stop the decline and the worsening course, Ottoman administrators had implemented some Western-style arrangements particularly since the Reign of Selim III. This edict, also known as the Gülhane Hatt-ı Hümayunu, which was declared in 1839 is almost the peak of these regulations. Even today, both the edict itself and its implementation continue to be debated among social scientists. While some social scientists criticize the regulations for being far from the realities of the country and "too Western," others support it as a "necessity" to prevent the collapse of the Empire. It needs noting, however, that reforms continued to be made, albeit in differing intensities, until the end of the political life of the Empire.

One of these reforms was in the field of administration. A regulation, enacted in 1864, marked a new are in the provincial administration of the Empire. The state system, which had been in effect for a long time in the provincial administration, was abandoned and the provincial system was adopted. New administrative units were established along with the new order. Another reform was the establishment of Provincial General Assemblies, which consisted of elected members from the livas (sanjaks) of corresponding provinces, in provincial centers under the chairmanship of governors. Members submitted petitions to the governor on the needs and demands of their regions on such issues as public works, development of agriculture and trade in the province. The decisions taken in the Assembly after discussion and the demands were sent to the Council of State (Şûrâ-yı Devlet), where the demands deemed admissible were approved. With the transition to the provincial system, a new order was established in Kastamonu and the members determined by elections in livas started to work in the provincial general assembly. The Assembly fulfilled the task assigned to it by negotiating the demands of the districts (kazas) in Kastamonu Province and notifying the central administration about these demands. In this study, the establishment of the Kastamonu Province and the working method of the provincial general assembly, which is an institution of this new system, is explained through various examples. By so doing, we believe that the implementation of the new provincial administration system in the province and its positive and negative consequences will be understood better. Moreover, it is our hope that the examples regarding the problems and demands of the Kastamonu Province of the period and its annexed - districts (kazas) will contribute to studies on local history of Kastamonu.

Keywords: Kastamonu, General Assembly, Provincial Administration 


\section{Giriş}

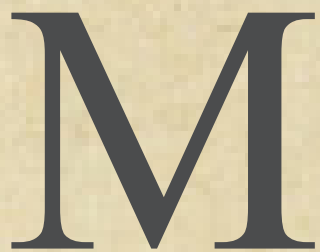
alî, idarî, askerî vb. birçok alanda önemli dönüşümlerin yaşandığ1 Tanzimat Dönemi öncesi Osmanlı İmparatorluğu'nda mülkî düzene bakıldığında, taşra teşkilatında hiyerarşik yapı; eyalet (beylerbeyilik, vilayet), sancak (liva), nahiye, köy ve mezra biçimindeydi. İlk olarak Osmanlı kuvvetlerinin 1354'te Gelibolu Yarımadası'na çıkışı ve akabinde meydana gelen fetihler neticesinde buraların idari bir yapıya kavuşturulması gereği duyulmuştu. 1361'den sonra Rumeli Beylerbeyiliği kurulmuş ve bunu Yıldırım Bayezid devrinde (1389-1402) teşkil edilen Anadolu Beylerbeyiliği takip etmişti. ${ }^{1}$ Beylerbeyiliklerin sayısının imparatorluğun sınırlarının genişlemesine paralel olarak arttığı görülmektedir. 1609 tarihli Ayn Ali Efendi’nin belirttiği listeye göre Osmanlı İmparatorluğu'nda mevcut beylerbeyilik sayısı otuz ikiye ulaşmıştı. ${ }^{2}$ XVIII. yüzyıla gelindiğinde eyaletlerin sayısı (kaptanlık, voyvodalık ve melikliklerle dâhil) kırk ikiye ulaşmıştı. ${ }^{3}$

XIX. asırda ise özellikle 3 Kasım 1839 tarihinde Tanzimat Fermanı'nın ilanından sonra ilk önemli düzenleme taşra teşkilatında yapılmıştı. II. Mahmud devrinde yapılan bazı düzenlemeler yetersiz kalmış, Avrupa ülkelerinin taşra yönetiminin örnek alınması düşüncesi olmakla birlikte devlet adamları, İmparatorluğun kendine özgü şartlarının da olduğu bilincinde idiler. Bunun için geçmişte yapılan düzenlemeler de göz önünde bulundurularak 1840-1852 yılları arasında taşra yönetiminde kalıcı bazı düzenlemeler yapılmıştı. ${ }^{4}$ Eyaletler sancaklara, sancaklar kazalara, kazalar da köyleri içine alan nahiyelere bölünmüştü. Eyaletlerin yönetimi valilere bırakılırken her valinin yanına bölge kuvvetlerine komuta edecek bir muhafız ile mali işleri kontrol edecek bir defterdar verilmişti. ${ }^{5}$ Tanzimat'ın herkesin gelirine göre vergi vermesi prensibinin uygulanabilmesi için hazine gelirlerinin tespiti gerekliydi. Bu amaçla eyalet ve sancak merkezlerine "muhassıl-1 emval" denilen kimselerle birlikte yanlarında kâtipler gönderilmişti. Ayrıca eyalet ve sancak merkezlerinde birer meclis oluşturulacaktı. Gayrimüslimlerin yaşadığı bölgelerde onlardan da iki temsilci bu meclislerde bulunacaktı. Sancak merkezlerinde, muhassıllar meclis başkanı olacaklardı ancak eyaletlerde ise bu görevi valiler yerine getirecekti. ${ }^{6}$

Taşra teşkilâtında düzenlemeler yapılırken eyaletlerin ve bunlara mülhak sancakların sayılarında da değişiklikler göze çarpmaktadır. Fazıla Akbal'ın 1831 yılındaki idari taksimatı listesine göre Osmanlı İmparatorluğu'nda on beş eyalet bulunmaktadır. Çalışma konumuz olan Kastamonu ise bu listede Anadolu Eyaleti’ne bağlı bir liva olarak gösterilmektedir. ${ }^{7}$ Taşra teşkilatına

1 Nejat Göyünç, Osmanlı Devleti’nde Taşra Teşkilâtı (Tanzimat’a Kadar), Osmanlı, Cilt 6, Yeni Türkiye Yayınlar1, Ankara 1999, s. 77.

2 Halil İnalcık, “Eyalet”, TDV İslâm Ansiklopedisi, Cilt 11, İstanbul 1995, s. 549.

3 Denizler ve mühim bazı nehirler üzerinde işleyen gemilerin sevk ve idaresi için teşkilatlanan kaptanlıklar ile yine Osmanlı İmparatorluğu'na bağlı olan hanlıklar, voyvodalıklar, meliklikler ve emirlikler idari taksimat açısından eyaletlerle eşdeğerdi. Ancak bunlar yerel isimlerle zikredilmeleri ve yarı bağımsız ya da imtiyazlı statülerinden dolayı eyalet olarak anılmamaktaydı. Orhan Kılıç, 18. Yüzyılın İlk Yarısında Osmanlı Devleti’nin İdarî Taksimatı Eyalet ve Sancak Tevcihatı, Elazığ 1997, S. $42-43$.

4 Musa Çadırcı, “Tanzimat”, Osmanlı, Cilt 6, Yeni Türkiye Yayınları, Ankara 1999, s. 184.

5 Enver Ziya Karal, Osmanlı Tarihi, Cilt 5, TTK, Ankara 2007, s. 191.

6 Musa Çadırcı, “Osmanlı Döneminde Yerel Meclisler”, Çağdaş Yerel Yönetimler, Ciltt 2, Sayı 5, Eylül 1993, s. 3-4.

7 Fazıla Akbal, “1831 Tarihinde Osmanlı İmparatorluğu’nda İdarî Taksimat ve Nüfus”, TTK, Belleten, Cilt 
dair bir diğer düzenleme kararı II. Mahmud devrinde kurulan redif askerî teşkilâtının daha iyi bir şekilde işlemesi için 1836 tarihinde toplanan "Meclis-i Şûra” da alınmıştı. Karara göre, Türkiye' de idarî yönetim müşirliklere ayrılıyordu. Bunlar Hüdâvendigâr Müşirliği, Konya Müşirliği, Ankara Müşirliği, Aydın Müşirliği, Erzurum Müşirliği ve Edirne Müşirliği. Kastamonu bu sırada Çankırı, Viranşehir (Safranbolu), Çorum ve Ankara sancaklarıyla birlikte Ankara Müşirliğini oluşturuyordu. ${ }^{8}$ Bu düzenleme Tanzimat'ın ilanına kadar devam etmişti. 1839'dan sonra Tanzimat'ın uygulandığ eyaletlerin sınırlarında bazı değişiklikler yapılmış, bazı sancaklar başka sancaklarla birleştirilerek yeni eyaletler oluşturulmuştu. Ankara Eyaletine Bozok ve Kayseri sancakları da bağlanmıştı. O sırada, Ankara Eyaleti Müşiri Davud Paşa'ya Tanzimat'ın uygulanması için gerekli düzenlemelerin yapılmasına dair talimat verilmiş fakat kısa bir süre sonra Tanzimat'ın gerektirdiği gibi yönetici olmadığı düşünülerek Haziran 1840'ta görevden alınmıştı. Yerine henüz Tanzimat'ın uygulandığı yerlerden olmayan Diyarbakır Eyaleti Müşiri Sadullah Paşa getirilmişti. ${ }^{9}$ Ancak onun da fazla görevde kalmadığı görülmektedir ki 1841 yılında Palaslı İsmail Paşa Ankara Eyaleti Müşirliğine tayin olunmuştu. ${ }^{10}$ Tanzimat'tan sonra yapılan değişikliklerden Kastamonu da nasibini almış ve 1841 'de Bolu Müşirliği adı ile teşkil edilen eyaletin içinde yer almıştı. Ancak 1846 yılındaki idari düzenlemede Kastamonu idarî statüsü yine değişmiş ve eyalet haline getirilmişti. ${ }^{11}$

İmparatorlukta mevcut eyalet ve sancaklar ile bunların zaman içerisinde geçirmiş olduğu değişimi 1847 yılından itibaren her yıl yayınlanan devlet salnamelerinden takip edebilmekteyiz. ${ }^{12}$ $\mathrm{Bu}$ salnamedeki listeye göre 1847 tarihinde Osmanlı İmparatorluğu'nda otuz dokuz eyalet (voyvodalıklar dâhil) bulunmaktadır. Salnameye göre Kastamonu Eyaleti şu sancaklardan oluşmaktaydı: Kocaeli (Muhassılı saniyeden Mustafa Efendi), Bolu (Kaymakamı Hacegândan Tâhir Efendi), Viranşehir (Kaymakamı Kapucıbaşı Cemal Ağa), Sinob (Kaymakamı Kapucıbaşı Mehmed Ağa). ${ }^{13}$

Tanzimat'ın ilanı üzerinden geçen yaklaşık on yıl süreye rağmen istenilen başarı henüz sağlanamamış, vergi toplamada eskinin alışkanlıkları (yolsuzluklar) devam ediyordu. Yine halkın can ve mal güvenliği sağlanamamıştı. İşte bu gibi nedenlerden ülke yönetiminde yeni bir düzenleme gereği duyulmuştu. 1849 yılında, Meclis-i Vâlâ tarafından hazırlanıp Sultan Abdülmecid'in onayı alınarak yürürlüğe giren yönetmelik, bir giriş, dokuz fasıl ve altmış sekiz maddeden oluşuyordu. Edirne Eyaleti'nden başlanarak ülke yönetiminin yeni baştan düzenlendiğini belirten yönetmelik, 1864 yılında yayımlanan "vilayet nizamnamesi”ne kadar yürürlükte kalmıştı. ${ }^{14}$

\footnotetext{
XV, Say1 60, Ekim 1951, s. 619-624.
}

8 Musa Çadırcı, “Anadolu'da Redif Askeri Teşkilâtının kuruluşu”, Cilt 8, Sayı 14, Mayıs 1963,s. 70-71.

9 Musa Çadırcı, Tanzimat Döneminde Anadolu Kentlerinin Sosyal ve Ekonomik Yapıları, TTK, Ankara 1991, s. 191.

10 BOA, C. DH. $107 / 5304$.

11 İlhan Şahin, "Kastamonu”, TDV İslam Ansiklopedisi, İstanbul 2001, Cilt 24, s.588.

12 Salnamelerin tarihi önemi için bkz. Ahmet Zeki İzgöer, "Osmanlı Salnâmelerinin Şehir Tarihi Bakımından Önemi”, Türkiye Araştırmaları Literatür Dergisi, Cilt 3, Sayı 6, 2005, ss. 539-552.

13 Salnâme-i Devlet-i Aliyye-i Osmaniyye, Def'a 1, Sene 1263, s. 81-88.

14 Çadırcı, Tanzimat Döneminde Anadolu Kentleri..., s. 218. Yönetmeliğin yürürlüğe girmesinden sonra Kastamonu Eyaletinin idarî taksimatında herhangi bir değişiklik olmamıştı. Kocaeli, Bolu, Viranşehir ve Sinob sancakları varlığını devam ettirirken, Kocaeli'de muhassıllık kaldırılarak diğer sancaklar gibi kaymakamlıkla idare edilmişti. Salnâme-i Devlet-i Aliyye-i Osmaniyye, Def’a 5, Sene 1267, s. 71. 


\section{Vilayet Nizamnamesi}

Balkanlarda Hıristiyan ahali arasında yaşanan huzursuzluk ve ayaklanmaların 1860-61'de tamamı Müslüman olan Suriye Eyaleti'ne de sıçraması görmezden gelinemeyecek bir tehlike işaretiydi. O dönem Hariciye Nazırı olan Fuad Paşa, bölgeye bizzat kendi gitmişti. Karışıklıklar hakkındaki tezkerelerinde Paşa, İmparatorluğun eyaletlerindeki kötü yönetim üzerinde büyük bir önemle durmaktaydı ${ }^{15}$ Ona göre eyalet ve sancakların büyütülmesi, valiliklerine ise tecrübeli ve muktedir kimselerin tayin edilerek yetkileri genişletilmeliydi. Valiler yalnızca mühim meselelerde merkeze danışmalıydılar. Merkezi idarenin bu durumda iş yükü hafifleyecek ve vükelâ, devletin önemli işleriyle ilgilenecek zaman bulacaktı. ${ }^{16}$ Cevdet Paşa ise bu düşüncede değildi. Ona göre, Osmanlı İmparatorluğu'nda eyaletlerin birçoğu coğrafî şartlar ve buralarda yaşayan ahalisi bakımından birbirlerine benzememekteydi. Ancak bu farklılıklar göz önünde tutularak mülkî 1slahata teşebbüs olunabilirdi. ${ }^{17}$

Lübnan' da Dürzîler ve Marunîler arasında çatışmalar çıkmış, Avrupalı devletler sözde olayları yatıştırmak için Lübnan'a asker çıkararak Osmanlı İmparatorluğu'nun iç meselesine doğrudan müdahale ediyorlardı. Ayrıca Osmanlı İmparatorluğunu da yanlarına alarak Lübnan'da sükûneti sağlamak için yeni bir statü hazırlamaya girişmişlerdi. İngiltere, Fransa, Rusya, Avusturya, Prusya ve Osmanlı temsilcilerinden oluşan bir komisyon, 9 Haziran 1861 tarihli Lübnan Nizamnamesini hazırlamışlardı. ${ }^{18}$ "Cebel-i Lübnan Nizamnamesi” ile Lübnan’a idarî, adlî ve malî tam bir özerklik veriliyordu. Nizamnameye göre Lübnan, Babıali idaresinde, yürütme kuvvetinin bütün yetki ve görevlerine sahip olan Hıristiyan bir mutasarrıfın idaresine veriliyordu (Reyhan, 2006/1, s. 171; Karal, 2007, s. 42; Tural, 2005, s. 83; Ortayl1, a.g.e., s. 51). ${ }^{19}$

Avrupalı büyük güçler, Lübnan'daki statünün benzerini İmparatorluğun diğer eyaletleri için de istiyorlardı. Osmanlı devlet adamları ise bu eğilimi engellemek ve merkezi idareyi her şeye rağmen güçlendirmek gayretinde idiler. Suriye' de yaşanan karışıklıklarla Niş’te vuku bulan ayaklanmalar arasında sıkışıp kalan Babıali reform programını hemen uygulamak zorundaydılar. 1863 senesi sonlarına doğru Âli ve Fuad Paşalar taşra yönetiminde reform uygulamasına giriştiler. ${ }^{20}$ $\mathrm{Bu}$ iş için imparatorluğun en “sıkıntılı” bölgelerinin belki de başında gelen Balkanlar' da (Niş’te) vali olarak oldukça başarılı icraata imza atan Midhat Paşa, İstanbul'a davet edilmişti. Sadrazam Fuad Paşa ve Midhat Paşa tarafından üzerinde çalışılarak hazırlanan bir nizamname, Heyet-i Vükelâ'nın tümü tarafından da onaylanmıştı. ${ }^{21}$

15 Bernard Lewis, Modern Türkiye’nin Doğuşu, TTK, Ankara 1993, s. 383.

16 Talât Mümtaz Yaman, Osmanlı İmparatorluğu Mülkî İdaresinde Avrupalılaşma Hakkında Bir Kalem Tecrübesi, İstanbul 1940, s. 159.

17 Enver Ziya Karal, Osmanlı Tarihi, Cilt 7, TTK, Ankara 2003, s. 153.

18 İlber Ortaylı, Tanzimat Devrinde Osmanlı Mahallî İdareleri (1840-1880), TTK Ankara 2000, s. 51.

19 Cenk Reyhan, “Cebel-i Lübnan Vilâyet Nizamnamesi”, Memleket Siyaset Yönetim, 2006/1, s. 171.;Enver Ziya Karal, Osmanlı Tarihi, Cilt 6, TTK, Ankara 2007, s. 42.;Erkan Tural, "Minyatür Bir Tanzimat Ülkesi: Lübnan ve 1861 Lübnan Vilayet Nizamnamesi”, Çağdaş Yerel Yönetimler, Cilt 14, Sayı 2, Nisan 2005, s. 83;;Ortayl1, a.g.e., s. 51.

20 Ortayli, a.g.e., s. 53.

21 Selda Kaya Kılıç, Tanzimat’tan Cumhuriyet'e Türkiye'de İl Yönetimi, Ankara Üniversitesi, Sosyal Bilimler Enstitüsü, Tarih Anabilim Dalı, Doktora Tezi, Ankara 1995, s. 66.; Roderic Davison, Osmanlı İmparatorluğu'nda Reform, 1856-1876, Çev. Osman Akınhay, Agora Kitaplığı, İstanbul 2005, s. 152-153. 
Vilayet Nizamnamesi Tanzimat'tan sonra taşrada yapılan ilk sistemli düzenlemelerdi. ${ }^{22}$ Nizamname ile ilk önce idari bölünmede yeni bir düzenlemeye gidilerek en büyük yönetim birimi olan eyaletten vilayete geçilmiştir. 1864 Vilayet Nizamnamesine ${ }^{23}$ göre vilayetler livalara(sancak), livalar kazalara, kazalar da karyelere (köylere) ayrılmaktaydı. İdarî birimlerin yöneticileri ise vilayetlerde geniş yetkilere sahip valiler, sancakta kaymakam ve kazalarda ise müdür idi. ${ }^{24}$

Tanzimat'ın ilanından kısa bir müddet sonra taşrada teşkil edilmeye başlanan meclisler, 1864 yılındaki düzenlemeden sonra da varlıklarını devam ettirmişlerdir. Vilayetlerde, livalarda ve kazalarda kurulan idare meclisleri, merkezden atanmış üyeleri haricinde yerel halk tarafından yapılan seçimle belirlenen üyelerden oluşuyordu. Ayrıca bir de her sancaktan seçilerek vilayet merkezine gönderilen iki Müslüman ve iki gayrimüslim üyenin katılımıyla kurulan Meclis-i Umumi-i Vilayet vardir.

Vilayet, liva ve kazaların yönetiminde meclislerin yanı sıra çeşitli memurlar da vardı. Bunlar vilayet yönetiminde vali, vilayet muhasebecisi, vilayet mektupçusu, umur-1 nafia memuru, umur-1 ziraat memuru, umur-1 hariciye memurlarıdır.

1864 Vilayet Nizamnamesi imparatorlukta bütün vilayetlerde aynı anda uygulamaya konulmamıştı. Bunun için Niş, Silistre ve Vidin eyaletlerinin birleştirilmesiyle Tuna Vilayeti teşkil olunmuş ve yeni sistem burada tatbik edilmeye başlanmıştı. Yeni vilayetin başına da Niş'te önemli başarılar elde eden Midhat Paşa getirilmişti. Midhat Paşa'nın Tuna Vilayetinde de oldukça başarılı olması devlet adamlarını cesaretlendirmiş ve ardından Bosna Vilayetinde üçüncü olarak da Edirne Vilayetinde sistem uygulanmıştı. ${ }^{25}$ Akabinde uygulama sırasıyla Haleb, Suriye, Trablusgarb ve Erzurum vilayetlerinde hayata geçmişti. ${ }^{26}$ Uygulama için tercih edilen yerlere bakıldığında çoğunlukla "sorunlu" denilebilecek bölgelerden seçildiğini görüyoruz. Tamamına yakını, Türk nüfusun azınlıkta olduğu vilayetlerdir. Tuna Vilayetinde sağlanan başarının bu bölgelerde de elde edilmesini ümit eden Babıali, bu sistemi tüm ülkede uygulayarak hem huzuru sağlayacak hem de karışıklıkları bahane ederek sürekli İmparatorluğun iç işlerine müdahale eden Avrupalı büyük güçlere bekledikleri fırsatı vermeyecekti.

\section{Düzenlemesi ve Kastamonu Vilayetinin Kuruluşu}

Yukarıda da belirtildiği üzere 1864 Vilayet Nizamnamesi’nin Tuna Vilayetinde görülen başarıları üzerine başka vilayetlerde de uygulamaya konulmuştu. Osmanlı İmparatorluğu idarecileri bu sistemin ülke sathında yaygınlaştırılmasını istiyordu. Devletin resmî gazetesi Takvim-i Vekayi'de bu amaç açıkça ilan ediliyordu: ${ }^{27}$

231864 Vilayet Nizamnamesi için bkz. Düstur, 1. Tertib, Cilt 1, s. 608-624,; ayrıca tam transkripsiyon metin için bkz. Mehmet Seyitdanlıŏlu, "Yerel Yönetim Metinleri III: Tuna Vilayeti Nizamnamesi", Çağdaş Yerel Yönetimler, Cilt 5, Sayı 2, Mart 1996, ss. 67-81,; 1864 Vilayet Nizamnamesi, Ed. Erkan Tural ve Selim Çapar, Türkiye ve Orta-Doğu Amme İdaresi Enstitüsü (TODAİE), Ankara 2015, ss. 374383.; Erkan Tural, "1861 Hersek İsyanı, 1863 Eyalet Teftişleri ve 1864 Vilayet Nizamnamesi”, Çağdaş Yerel Yönetimler, Cilt 13, Say1 2, Nisan 2004, ss. 93-123. 
“... mevki-i tecrübe imtihan olarak teşkil olunan Tuna Vilayeti idaresince muhassenatı görüldükçe diğer kıtaat-1 mülkiyye idarelerinin de bi’t-tedric o usûl ve kaide dairesine alınmasıyla şâyân buyurulmuştur. Vilayet Nizamnamesinin ahkâmının el-hâletü hazihi müteşekkil olan devâir hâricindeki eyâlâtın kaffesinde ve şu aralık masrafça hazine-i celileye bâr olmayacak sûrette mevki-i icraya konularak eyâlet nam ve unvanının bi'l-umûm vilayete tahviline emr ü ferman-1 isâbet-beyân-1 şeref-sünûh ve sudûr buyurulmuş ve iktizalarının sırasıyla icrasına teşebbüs ve mübaşeret k1lınmıştır."

21 Haziran 1867 (18 Safer 1284) tarihinde 22 maddelik bir talimatname yayınlanmıştır. Talimatnamenin girişbölümünde dahaevvelyapılan düzenlemelerdenherkesinmemnun olduğundan, bu usulün bütün ülkede uygulamaya konulması gerektiği belirtilmekte idi. Talimatnameye göre vilayetler livalardan, livalar kazalardan, kazalar ise nahiye ve köylerden oluşuyordu. Bu idari birimlerin yöneticileri ise; vilayette vali, livada mutasarrıf, kazada kaymakam, nahiyede müdür ve köyde muhtardır. ${ }^{28}$ Talimatname ile taşra idaresinde 1864 nizamnamesinden farklı olarak nahiye idarî birimi dikkat çekmektedir. Öte yandan livada daha evvel kaymakam unvanı verilen idarecinin mutasarrıfa keza kazada ise müdür olan unvan kaymakama tahvil olunurken, müdürün ise nahiye idarecisi için kullanıldığı görülmektedir.

Prof. Tuncer Baykara'ya göre bu talimatın en önemli özelliklerinden birisi bir süredir fonksiyonunu kaybetmiş olan "kaza" ve "nahiye"lerin büyük kısmının ortadan kalkmasıdır. Örnek olarak da Kastamonu'nun 93 olan kaza sayısının 18'e düştüğünü söyler. Yine Baykara'ya göre 1867 düzenlemesi tarihi mirasa göre olmaktan ziyade yeni coğrafi şartlara göre düzenlenmişti. Ayrıca düzenleme için yeterince hazırlık yapılmadığı fikrindedir. ${ }^{29}$

1864 Vilayet Nizamnamesi'nin yukarıda da belirtildiği üzere Tuna Vilayetinde başarılı olmuş ve 3'ü Rumeli, 1'i Anadolu, 2'si Arabistan, 1'i Irak ve diğer 1'i de Afrika'da olmak üzere 8 vilayet teşkil edilmişti. 1867 senesinde bunlara 12 yeni vilayet daha eklenmesi kararlaştırıldı. Meclis-i Mahsusa ve Meclis-i Vâlâ'da bu konuda müzakereler yapılmış ve birtakım kararlar alınmıştı. Vilayetler dâhilinde bulunan livaların kaymakamlarına "mutasarrıf", kaza müdürlerine "kaymakam", nahiye zabıta memurlarına "müdür" unvanı verilirken, vilayet muhasebecilerine eskisi gibi "defterdar", liva mal müdürlerine "muhasebeci" ve kaza mal kâtiplerine "mal müdürü" unvanlarının verilmesi uygun görülmüştü. Ayrıca vilayet nizamnamesi gereği daha evvel teşekkül eden vilayetlere idare-i mülkiye için bir heyetle beraber birer kaymakam tayin edileceğinde ilk başta buralara "merkez kaymakamları" gönderilmişti. Fakat daha sonra tasarruf düşüncesiyle çoğu vilayetten bu kaymakamlıklar ilga olunup yerlerine vali muavini tayin edilmişti. Merkez-i Vilayet olan sancağın mülkî işleri bu muavinlere verilmişti. Müzakereler esnasında, teşekkül edecek olan vilayetlerde icap eden mahallere gayrimüslim tebaadan birer muavin gönderilerek, o vilayetlerdeki ecnebilerin işlerinin idaresinin de onlara havale olunması düşünülmüştü fakat hem livanın idaresi hem de ecnebilerin işlerinin bir memura verilmesi işlerin gecikmesine sebep olacağından, gayrimüslim nüfusun olduğu vilayetlerde bu işler merkezde bulunacak muhasebeciye verilmesi uygun bulundu. Gayrimüslimlere ait işlerin olmadığ 1 vilayetlerde ise merkez-i liva umurunun muavinler vasıtayla idaresi kararlaştıııldı.

28 Kılıç, a.g.t., s. 79-80.

29 Tuncer Baykara, Anadolu’nun Tarihî Coğrafyasına Giriş I Anadolu’nun İdarî Taksimatı, Türk Kültürünü Araştırma Enstitüsü Yay., Ankara 1988, s. 130-131. 
Yapılan müzakereler neticesinde Haziran 1867 'de 12 vilayetin teşkil edilmesine karar verildi. $\mathrm{Bu}$ vilayetlerden birisi de Kastamonu Vilayeti idi. Vilayete mülhak sancaklar ve bunlara bağlı kazalar şunlardır: Bolu ma’ Ereğli Sancağı, Sinob Sancağı, Kastamonu Sancağı ve Kengırı Sancağı. Vilayetin valiliği ise Rumeli valisi Tevfik Paşa'ya tevdi edilmişti (BOA, İ.MMS. 133/5692, 29 Muharrem Sene 1284, 2 Haziran 1867). ${ }^{30}$ Mehmed Tevfik Paşa temmuz sonunda Kastamonu'ya giderek vazifesine başlamıştı. ${ }^{31}$ Fakat vilayet teşkil edilmeden kısa bir süre önce Kastamonu Eyaleti Mutasarrıfı Hamdi Paşa, eyaletteki “başarılı” bir şekilde hizmet ettiğinden bahisle Kastamonu'nun vilayete tahviliyle görevine devam etmesi aksi takdirde yeni teşkil edilen vilayetlerden birisine tayini talebini bildirmişti. ${ }^{32}$

Tablo 1. Kastamonu Vilayetinin Havi Olduğu Livalar ve Kaymakamlık Suretiyle İdare Olunan Kazaları: ${ }^{33}$

\begin{tabular}{|c|c|c|c|}
\hline Kastamonu Sancağı & Kengırı Sancağı & Sinob Sancağı & Bolu Sancağı \\
\hline $\begin{array}{l}\text { Taşköprü } \\
\text { Kaymakamlığ1 }\end{array}$ & $\begin{array}{l}\text { Çerkeş } \\
\text { Kaymakamlığı }\end{array}$ & $\begin{array}{l}\text { İstefan } \\
\text { Kaymakamlığ } 1\end{array}$ & Göynük Kaymakamlığı \\
\hline $\begin{array}{l}\text { Daday } \\
\text { Kaymakamlığı }\end{array}$ & $\begin{array}{l}\text { Kalecik } \\
\text { Kaymakamlığ }\end{array}$ & $\begin{array}{l}\text { Boyabad } \\
\text { Kaymakamlığ } 1\end{array}$ & Gerede Kaymakamlığı \\
\hline Araç Kaymakamlığı & & & Ereğli Kaymakamlığı \\
\hline $\begin{array}{l}\text { İnebolu } \\
\text { Kaymakamlığ1 }\end{array}$ & & & Bartın Kaymakamlığı \\
\hline \multicolumn{4}{|l|}{ Tosya Kaymakamlığı } \\
\hline $\begin{array}{l}\text { Zağferanbolu } \\
\text { Kaymakamlığ1 }\end{array}$ & & & \\
\hline
\end{tabular}

Kastamonu Eyaleti'nin vilayete tahvili ile birlikte teşkilat-1 cedide gereği yeni memurlar tayin olundu. Vilayet ve sancaklara tayin olunan yöneticiler aşağıda gösterilmiştir: ${ }^{34}$

\begin{tabular}{|l|l|l|l|l|l|}
\hline $\begin{array}{l}\text { Vilayet ve } \\
\text { Sancaklar }\end{array}$ & Muavinlik & & & & Mülahazat \\
\hline $\begin{array}{l}\text { Kastamonu } \\
\text { Vilayeti }\end{array}$ & Burdur & $\begin{array}{l}\text { Maliye Kâtibi } \\
\text { Esbak Halim } \\
\text { Bey }\end{array}$ & - & - & \\
\hline Sinob Sancağı & - & - & $\begin{array}{l}\text { Kaymakamı } \\
\text { bulunan } \\
\text { Tevfik Paşa }\end{array}$ & - & - \\
\hline
\end{tabular}

30 BOA, İ.MMS. 133/5692, 29 Muharrem Sene 1284 (2 Haziran 1867). Kastamonu'dan başka teşkil edilen vilayetler şunlardır: Aydın, Ankara, Cezayir-i Bahr-i Sefid, Hüdâvendigâr, Diyarbakir, Sivas, Trabzon, Konya, Selanik, Yanya, Üsküb vilayetleri.

31 BOA, A. MKT. MHM. 388/42, 13 Temmuz Sene 1283 (25 Temmuz 1867).

32 BOA, A. MKT. MHM. 378/88, 9 Mart Sene 1282 (20 Mart 1867).

33 BOA, İ. ŞD. $7 / 349$, lef 5.

34 BOA, İ. MVL. 575/25823. 


\begin{tabular}{|l|l|l|l|l|l|}
\hline Bolu Sancağı & - & - & $\begin{array}{l}\text { Kütahya } \\
\text { Kaymakamı } \\
\text { Esbak Asaf } \\
\text { Pasa }\end{array}$ & - & \\
\hline $\begin{array}{l}\text { Nengde } \\
\text { Kaymakamı } \\
\text { Sancağı }\end{array}$ & - & - & $\begin{array}{l}\text { Kaymak Said } \\
\text { Esbasa } \\
\text { Paşa }\end{array}$ & - & \\
\hline Ereğli & - & - & $\begin{array}{l}\text { Kaymakamı } \\
\text { Bulunan } \\
\text { Dilaver Paşa }\end{array}$ & İbkâ \\
\hline
\end{tabular}

Ancak vilayet mektupçuluğuna daha evvel tayin olan Halim Bey’in istifa etmesi üzerine, yerine 6.000 kuruş maaşla Bedri Bey gelmişti. ${ }^{35}$

Yeni düzenin tesisi için yapılacak icraatı anlatmak ve vilayet dâhilindeki ahaliyi tetkik ve teftiş etmek maksadıyla vilayeti dolaşmaya çıkan Vali Mehmed Tevfik Paşa ilk önce Sinop'a gitmişti. Buradaki incelemelerini tamamladıktan sonra Ereğli'ye hareket eden Paşa, Ereğli'de aynı şekilde gerekli çalışmaları yaparak önce Bolu akabinde Kengırı sancaklarına gitmeye karar vermişti. Mehmed Tevfik Paşa, gittiği yerlerde muhtar ve ihtiyar meclislerinin seçimlerinin tamamlandığını sadarete bildiriyordu. Seçimler yapılmasına yapılmıştı ama Paşa'nın ifadesinden anlaşıldığına göre bu işler yapılırken birtakım ihtiyaçlar, yetersizlikler ortaya çıkıyordu. Evvela bu meclislerin görmeye mezun oldukları işlere dair ellerine verilmesi gereken talimatların, kazalardaki meclislerin seçim pusulalarının ve ahaliye anlatılması gereken muamelata dair birtakım evrakın kesretine göre elle yazılmasının mümkün olmadığı idi. Muhtar ve ihtiyar meclisleri seçimlerinin mevcut memurlar marifetiyle yaptırılabilmiş ise de nizamnamede belirtilen usule göre kaza, liva ve vilayet meclislerinin seçimlerinin yapılması için evvela her kazaya kaymakam tayin olunması gerektiğini ifade ediyordu. ${ }^{36}$

Yukarıda belirtildiği üzere vilayetin artan resmî işlerinin geciktirilmeden, düzenli bir şekilde yapılabilmesi için şimdilik bir litografya destgâhıyla bir litografyacıya ihtiyaç olduğu merkeze bildiriliyordu. Talep üzerine vilayetlere gönderilmek amacıyla Avrupa'dan getirtilen destgâhlardan birinin Kastamonu'ya gönderilmesi ve yine bu işe ehliyeti onaylanmış olan İsmail Ağa'nın 900 kuruş maaşla tayinine karar verilmişti. ${ }^{37}$

Eyaletten vilayete geçişten sonra eksikliği hissedilen bir diğer konu da hükümet tarafindan tayin edilen yeni memurlarla birlikte artan daire, yeni bina meselesidir. Vali Mehmet Tevfik Paşa, sadarete yazılan tahriratta vilayetin teşkiliyle birlikte geldiği günden beri gayret ve çalışmalarının bayındırlık işlerinde henüz semeresinin, beklenilmesine karşın biraz tehir etmiş gibi göründüğüne dair öz eleştiri yapıyordu fakat Paşa'nın ifadesine göre gerek merkez-i vilayette gerekse tayin edilecek kaymakamlık mahallerinde teşkil edilecek meclislerle, memurların ikamesine yer bulunmuyordu. Bu nedenle, ilk önce düşünülecek şey, vilayet merkezindeki memurları ve meclisler azasının ikamelerine lüzumu olan mahallin tedariki meselesini halletmekti. Vilayet merkezi olan nefs-i Kastamonu'da bir hükümet konağı elbette vardı. Ancak mevcut hükümet konağı binası bir 
vali odasıyla memurlar ve eski ketebeden tahrirat, muhasebe, evkaf ve arazi memur ve ketebesi odalarından ibaretti. Bu sebeple yeni bir daire-i mahsusa inşası elzemdi. $\mathrm{Bu}$ inşaatın kaide ve usulüne göre vilayetçe münakasasının ${ }^{38}$ icrasıyla maktuan talibine bırakılması lazım gelse de burada Kastamonu'da öyle münakasa ile bina yapılmasını üstlenecek adam bulunmayacağı söyleyen vali devamında biraz da abartılı olsa gerek “... usûlen zirầ üzerine hesab yapmayı dahi bilür usta bulunamayub..." diyerek emaneten inşa ettirmekten başka çare olmadığını merkeze iletmişti. ${ }^{39}$ Hükümet konağının genişletilmesi ve resmî evrakın hıfz olunması için yapılacak mahzenin keşif defteri ve resmî vilayet tarafından Meclis-i Vâlâ-yı Ahkâm-1 Adliye'ye havale olunmuştu. ${ }^{40}$ Hazırlanan keşif defterine göre inşaatların tahmini bedeli 1 yük 16. 361 kuruştu. Merkezi idarece tetkik edildikten sonra vilayete inşaatın yapımına dair mezuniyyet verilmişti. ${ }^{41}$

Mehmed Tevfik Paşa'nın yaşadığı bir diğer mesele de, teşkilât-1 cedide icabınca açıkta kalan müdürler ve ketebeye münasip yerler bulunmasına dair tahriratla merkezden gelen taleplerdi. $\mathrm{Bu}$ isteklerden bunalmış olacak ki Paşa'nın vilayetten talep olunmadıkça merkezden ketebe ve müdür gönderilmemesine dair Meclis-i Vâlâ’ya havale olunan tahriratı bunu göstermektedir. ${ }^{42}$

Mehmed Tevfik Paşa'dan sonra valilik makamına Erzurum Valisi Mehmed Reşid Paşa tayin edilmişti. ${ }^{43}$ Mehmed Reşid Paşa memuriyet mahaline gitmeden evvel teşkilât-1 cedideye dair yapılacak 1slahata dair bilgi vermek için İstanbul'a gitmek isteğini merkeze bildirmiş fakat buna gerek olmadığı kendisine ifade edilmişti. ${ }^{44} \mathrm{Bu}$ arada, tayinin kış mevsiminde olması devrin ulaşım koşullarının zorluğu nedeniyle Kastamonu Vilayeti Valisi Mehmed Tevfik Paşa'ya yerine vekil bırakmaması ve yeni vali gelinceye kadar görevine devam etmesi bildirilmişti. ${ }^{45}$ Yeni valinin Kastamonu'ya gelip görevine başlamasıyla birlikte vilayet sisteminin tüm kurumlarıyla vilayette tatbiki hususunda çalışılmaya başladığı görülmektedir. Ancak Mehmed Reşid Paşa da tıpkı selefi gibi muhtelif zorluklarla karşılaşmıştı. Kastamonu Vilayetinde istihdam olunan memurlar için tahsis olunan 2 yük 17.600 kuruş ödeneğin yeterli olmaması hasebiyle Dersaadet'e yapılan müracaat neticesinde mezkûr ödeneğe 20.000 kuruş daha ilave yapılmıştı. Fakat kaymakamlıkların maaşlarının 1.250 kuruştan 2.000, müdürlüklerin 416 kuruştan 800 kuruş raddelerine yükseltilmesi ve kaza mal müdürlerine 290 kuruş ve meclisler azalarına da 80 kuruş maaş verilmesi gerektiği ancak maaşların hali hazırda çok aşağı mertebede olduğunu söylüyordu. Valiye göre bu şartlar altında kaymakamlık, müdürlük vs. memuriyetler için ehil ve erbâb yani nitelikli adam bulunamayacaktı. Vilayet teşkilatının uygulanması ve bunun semeresinin görülmesi de bu nitelikli, muktedir memurin takımının vazifelendirilmesiyle mümkün olabilirdi. $\mathrm{Bu}$ da yeterli derecede maaş ödenmesine bağlıydı. İște vilayetten Şûra-yı Devlet'e gönderilen iki kıta tahriratta meselenin çözümü için söz

38 Münakasa; Devlet ya da bir müessese tarafından bir malın veyahut bir işin indirilmeye konulması babında kullanılan tabirdir. Açık ve kapalı zarf olmak üzere iki şekilde yapılan münakasa usulünde, konu olan mal ya da iş en fazla indirim yapana ihale edilir. Mehmet Zeki Pakalın, Osmanlı Tarih Deyimleri ve Terimleri Sözlüğü II, İstanbul 1993, s. 616.

39 BOA, İ. MVL. 582/26152, 17 Ağustos Sene 1283 (29 Ağustos 1867).

40 BOA, MVL. 739/44, 21 Teşrinievvel Sene 1283 (2 Kasım 1867).

41 BOA, İ. MVL. 582/26152, lef 5, 17 Şaban Sene 1284 (14 Aralık 1867), A. MKT. MHM. 396/54, 21 Şaban Sene 1284 (18 Aralık 1867).

42 BOA, MVL. 740/41, 16 Teşrinievvel Sene 1283 (28 Ekim 1867).

43 BOA, A. MKT. MHM. 396/27, 17 Şevval Sene 1284 (11 Şubat 1868).

44 BOA, A. MKT. MHM. 399/87, 28 Kanunievvel Sene 1283 (9 Ocak 1868).

45 BOA, A. MKT. MHM. 397/97, 12 Ramazan Sene 1284 (7 Ocak 1868). 
edilen vilayet tahsisatına 20-25 bin kuruşun daha ilavesi gerekiyordu.

Vilayetçe istenilen zammın gerekliliği, merkezi yönetim tarafından da valinin ifadesiyle "tasdik ve itiraf olunmakla" birlikte konu hakkında Maliye Nezaretiyle de yapılan yazışmalar neticesinde, beklenilen cevap verilmişti. Burada vilayet ve liva merkezi idare meclisleri azasına maaş verilmesinden sarf-ı nazar olunacağı ve Kastamonu Vilayeti İdare Meclisleri azasının senelik 10.000 kuruş kadar olan maaşlarının vilayet tahsisatına eklenmesiyle maaşların ödenmesi ve 20.000 kuruşa yükseltilmesi lüzumu ve mecburiyeti tasdik edilerek gereğinin icrası bildiriliyordủ. Maliye Nezareti mütalaasına göre, meclisler azalarının maaşları ileride ilga olunacak olsa bile şimdilik böyle karar olmamasından dolayı vilayetin tahriratta belirttiği hususlar ve talep edilen tahsisat Şûrâ-yı Devletçe uygun bulunarak Kastamonu Vilayetine gerekli yetkinin verilmesine ve hazinece de gereğinin yapılması hususunun Maliye Nezaretine havalesine karar verilmişti. ${ }^{46}$

Tanzimat'ın ilanıyla birlikte imparatorluğun taşra idaresinde birtakım meclisler kurulmuştu. Muhassıllık meclisi, büyük meclis vs. meclisler, 1864 Vilayet Nizamnamesi'nin ilanıla birlikte isimlerinde ve görevlerindeki kimi değişikliklerle birlikte varlıklarını devam ettirmişlerdi. Nizamname gereği vilayetlerde, livalarda ve kazalarda tesis olunan bu meclislerin Kastamonu Vilayeti'nde de açılması için çalışıldığı görülmektedir. Kastamonu Vilayeti valiliğine tayin olunduğu haberini Erzurum'da aldığı andan itibaren Mehmed Reşid Paşa, vilayette yapılan sslahata dair vilayetteki memurlardan telgraf vs. yollarla bilgi almıştı. Alınan cevapta ise henüz yeni teşkilâta mübaşeret olunmadığının bildirilmesi üzerine durumu sadarete bildirmişti. Kastamonu'ya vardığında ise “...yalnız ihtiyar meclislerinin teşkiliyle iktifa olunduğunu, mümkün olduğu kadar nahiye müdürleriyle kaza kaymakamları tayin kılınmış ise de onlarında dolgun maaşlı memuriyet ümid ve efkârına düşürülerek ekserisi mahal-i memuriyetlerine gönderilmeyüb..." diyerek bunun vilayette yaygın bir hâl olduğunun müşahede edildiğinden bahsediyordu. Bu kimseleri ikna etmek için konuşulduğunu ve memuriyet mahallerine gitmemeleri durumunda yerlerine başkalarının tayin kılınacağının beyanıyla çoğunun ikna edildiği şeklindeki sözleriyle vilayetteki vaziyete dair kötü bir tablo çiziyordu. Kendisinin gece-gündüz çalışarak, evvela kaymakamlık meclislerinin ve ikinci olarak liva meclislerinin talimat-1 seniyyeye uygun bir biçimde seçimlerinin icra olunduktan sonra (intihabnâmeleri getirtilerek) azalarıyla mümeyyizlerinin maaşları, vilayet meclisinin teşkilinden sonra onların maaşlarılla birlikte ödenmesi hususunda gerekli talimatların verildiğini ifade ediyordu. Öte yandan vilayet meclisleri aza ve mümeyyizlerinin de seçimleri livalar tarafından tasdik olunmak üzere sıfat-1 mutlak ile vasıflanan zevatın isimlerini içine alan "meclis-i tefrik" teşkil edilmiş ve burada usulüne uygun olarak hazırlanan özel evrak tanzim olunarak bağlı livalara gönderilmişti. Neticede tüm meclislerin teşkili ve memurların tayini ayın $15^{\prime}$ 'i ya da en son 20 'sine (tahriratın yazılma tarihi H. 9 Zilhicce/R. 21 Mart) tamamlanacaktı. ${ }^{48}$

Kaza ve liva meclislerinin teşkilinden sonra Vilayet İdare Meclisi azaları ve Meclis-i Temyiz-i Hukuk ve Meclis-i Cinayet mümeyyizliği seçimlerinin yapılacağı yukarıda da belirtildiği üzere vali tarafından ifade edilmişti. Vilayette (ikinci olarak livalarda) teşkil edilen Meclis-i Temyiz-i

46 BOA, İ. ŞD. 7/349, 1 Rebiülevvel Sene 1285 (22 Haziran 1868).

47 Meclis-i Tefrik; Vilayet merkezinde İdare Meclisi’nin doğal üyeleri olan müfettiş-i hükkâm, muhasebeci, mektubcu, meclis-i hukuk ve meclis-i cinayette bulunan deavi memurları ve vilayet merkezinde bulunan müftü, kadı ve gayrimüslim milletlerin ruhani reisleri tarafından valinin başkanlığında kurulan bir meclistir. Bkz. 1864 Vilayet Nizamnamesinin dördüncü fasıl, beşinci maddesi. 
Hukuk, müfettiş-i hükkâmın başkanlığında üçü Müslüman, üçü gayrimüslim olmak üzere seçimle belirlenen ve "mümeyyiz" adı verilen altı azadan mürekkeb olacaktı. Ayrıca mecliste, umur-1 hukukiyeye vâkıf, devlet tarafından görevlendirilen bir memur da bulunacaktı. Meclis-i Temyiz-i Hukuk tarafından görülüp karara bağlanan davalar, müfettiş-i hükkâm ve mümeyyizler tarafından mühürlenen mazbatalarla valiye arz olunacaktı. Valinin bunların icrasına dair kararı verecek ancak yetkisi hâricinde olanları merkezi hükümete arz edecekti. ${ }^{49}$

Vilayette (ikinci olarak livalarda) teşkil edilen Meclis-i Cinayet de müfettiş-i hükkâmin başkanlığında olacaktı. Yine bu mecliste mümeyyiz adı altında seçimle belirlenen üç Müslüman ve üç gayrimüslim aza tarafında teşkil edilecekti. Ayrıca mecliste devlet tarafından görevlendirilmiş, kanunlara vâkıf bir memur da bulunacaktı. Cinayet Meclisi kararları da Temyiz-i Hukuk Meclisi kararlarında olduğu gibi başkan ve mümeyyizler tarafından mühürlenen mazbatalar valiye arz olunacaktı. Vali, devlet tarafından kendisine tanınan yetki dairesinde son sözü söyleyecek, yetki hududu hâricindekileri ise merkeze göndermekle mükellefti. ${ }^{50}$

Valinin maiyetinde vilayette teşkil edilen bir diğer meclis de Meclis-i İdare-i Vilayettir. Bu meclis müfettiş-i hükkâm-1 şer’iyye, muhasebeci, mektubçu, hâriciye müdürü ile üç Müslüman ve üç gayrimüslim reayadan seçilmiş kimselerden oluşacaktı. Valinin başkanı olduğu mecliste vali olmadığı zaman kendisinin uygun görüp tayin edeceği memurinden birisi vekâlet edecekti. İdare Meclisi mülkiye, maliye, hariciye, nafia ve ziraat işlerine dair maddelerin icraatına ait olan müzakerata memurdu. Ancak meclis hukuk işlerine müdahale etmeyecekti. ${ }^{51}$

1864 Vilayet Nizamnamesinin sonunda madde-i mahsusa olarak İdare Meclisi azası, deâvî, temyiz-i hukuk ve cinayet meclisleri mümeyyizlerinin iki senede bir yarısı değiştirilip yerlerine görev süreleri dolanların da tekrar seçilebilmeleri hakkına sahip olarak, her sene azanın da yarısı için seçim icra olunacağı belirtiliyordu.

Vilayette Meclis-i Temyiz-i Hukuk, Cinayet Meclisi mümeyyizliği ve Vilayet İdare Meclisi azalığı için seçim yapılmış ve ekseriyyet-i ara (oy çokluğu) ile bunlar belirlenmişti. Nizamname-i Mahsusa'da beyan ve izah edildiği şekliyle teşkil edilen meclislerin aza ve mümeyyizliğine intihap ve tayin olunacak kimselerin meclisteki dağılımı imparatorluktaki unsurların nüfus sayısı ve hane miktarına göre olacaktı. Kastamonu'da bu dönemde Rum ve Ermeni nüfusun varlığını görüyoruz. Ancak Kastamonu'da Ermeni milletine mensup çoğunlukla demircilik ve boyacılıkla iştigal eden 18 hane, 30 civarında nüfusu bulunuyordu. Ayrıca livada toplanmış heyette ve kurasında (köylerinde) cüziyyet üzere bulunanlar da göçebe ve Kıbtî "taifesinden" olmaları ve Rum milletinin ise 200 hane civarında olduğu gibi liva heyetinde de çoğunlukta olduklarından nispet kaidesini uygulayarak Ermenilerden sarf-1 nazar edilmişti. ${ }^{52}$ Rumlardan İdare-i Vilayete bir, cinayet ve temyiz-i hukuka iki nefer tayin olunmuştu. Fakat Bolu ve Kengırı sancaklarında merkez sancağa nispetle çoğunluk olan Ermeni milletinden livalarınca idare, temyiz-i hukuk ve cinayet

49 Meclis-i Temyiz-i Hukuk'un teşkili ve görevleri için nizamnamenin bkz. on sekiz, on dokuz, yirmi ve yirmi birinci maddeleri.

50 Bkz. Vilayet Nizamnamesi, yirmi iki, yirmi üç ve yirmi dördüncü maddeler.

51 Bkz. Vilayet Nizamnamesi, on üç ve on dördüncü maddeler.

52 Vilayetin resmî rakamlarına göre Kastamonu mahalleleri ve Bedamic Karyesinde (toplam 32 mahalle ve karye) Ermenilere ait 18 hane ve 66 nüfus var iken Rumlar ise 165 hane ve 524 nüfustur. Müslümanlarda ise durum 2.955 haneye karşılık 5.190 nüfustur. Bkz. Salnâme-i Vilâyet-i Kastamonu, Def’a 1, Sene 1286, s. 105. 
için aza mümeyyizleri seçilerek tayin kılınmış ve valinin ifadesine göre vilayette teşkilat ikmal olunmuştu. ${ }^{53}$ Vilayetin müfettiş-i hükkâmlığına İstanbul Kadısı Müsteşarı Mehmed Şükrü Efendi tayin olunmuştu. ${ }^{54}$ Kastamonu Vilayetinin 1869 yılında yayınlanan ilk salnamesinde Vilayet İdare Meclisi, Meclis-i Temyiz-i Hukuk ve Cinayet şöyle idi: ${ }^{55}$

\begin{tabular}{|l|l|}
\hline \multicolumn{2}{|c|}{ Reis } \\
\hline Seçilmiş Aza & Tabii Aza \\
\hline Şeyh Hafiz Mehmed Said Efendi & Vilayet Defterdarı (Nazif Efendi) \\
\hline Hacı Mustafa Bey & Vilayet Mektubcusu (Izzet Efendi) \\
\hline Salim Efendi & Vilayet Müfettiş-i Hükkâmı (Şükrü \\
\hline Bedos Ağa & \\
\hline \multicolumn{2}{|c|}{ Meclis Başkâtibi Rauf Bey } \\
\hline \multicolumn{2}{|c|}{ Mukayyid Selim Bey } \\
\hline
\end{tabular}

Vilayet Meclis-i Temyiz-i Hukuk ve Cinayet ise şu şekilde teşekkül etmişti:

\begin{tabular}{|l|l|}
\hline \multicolumn{2}{|c|}{ Reis } \\
\hline Aza & Azayet Müfettiş-i Hükkâmı (Sükrü Efendi) \\
\hline Hacı Hidayet Ağa & Bahaeddin Efendi \\
\hline Şeyh Said Efendi & Yani Ağa \\
\hline Hafiz Mehmed Emin Efendi & Dimitri Ağa \\
\hline \multicolumn{2}{|c|}{} \\
\hline Meclis Başkâtibi Haci Ali Efendi \\
\hline Mukayyidi Ömer Bey \\
\hline
\end{tabular}

\section{Kastamonu Vilayeti Meclis-i Umûmisi}

1864 Vilayet Nizamnamesinin 25. maddesinde belirtildiği üzere her vilayette bir Meclis-i Umûmi-i Vilâyet teşkil edilecekti. Bu meclis, her sancaktan seçilip gönderilen iki Müslüman ve iki gayrimüslim azadan oluşacaktı. Başkanlığı vali de olacak olan meclisin ikinci başkanı ise memurlar içinden vali tarafından tayin edilecekti.

Meclis-i Umûmi senede bir defa, vilayet merkezinde toplanacaktı fakat toplantı ve müzakereler kırk günü geçmeyecekti (Madde 26).

Vilayet Umûm Meclisi evvela dâhil-i vilayette bulunan turûk-1 sultaniyye (devlet yolları) ile kaza ve köylerde bulunan turûk-1 husûsiyyenin (özel yollar) tesviyesi, muhafazası ile sancak ve kaza ahalisinin bu hususlardaki isteklerini tetkik ve müzakere edecekti. Ziraat ve ticaretin geliştirilmesine dair konuların görüşülmesi ve sancak, kaza ve köy vergilerinin değiştirilmesi ya da bu hususlardaki görüşlerini bildirmeye memurdu (Madde 27).

Meclis-i Umûmiye gelen azalar, geldikleri sancak ve kazalara ait görüşülmesini istedikleri konulara dair dilekçeleri meclise tebliğe memur olup ancak bunların hangilerinin gündeme alınıp

53 BOA, ŞD. 1638/2, 17 Nisan Sene 1284 (29 Nisan 1868).

54 BOA, İ. DH. 585/40764, 29 Ramazan Sene 1285 (13 Ocak 1869).

55 Salnâme-i Vilâyet-i Kastamonu, Def'a 1, Sene 1286, s. 32-33. 
müzakere edileceği hususunda yetki valide idi. Görüşülen konularda meclis yalnızca görüş bildirme yetkisine sahip iken bu mevzularda alınan kararlarda icra yetkisi hükümet-i seniyyeye aitti. Meclisin yetkisi dâhilinde müzakere edilen konularda alınan kararları içeren mazbatalar hazırlanır ve bunlar vali tarafından merkezî hükümete arz ve tebliğ olunurdu. Merkezi idarenin vereceği nihai karara göre bunlar uygulanırdı (Madde 28).

Meclis-i Umûmi azalarının seçimi ise oldukça karmaşıktı. Evvela meclisin içtima tarihinden bir ay önce livaya bağlı her kazadan belirlenecek dörder üye liva merkezine gelerek liva ve kaza ahalisinden aza olabilme şartlarını haiz üç azayı seçecekti. Mutasarrıf ise seçilmiş olan bu üç azayı vilayet merkezine bildirecekti. ${ }^{56}$

Vilayet Umûm Meclisi'nde görüşmeler halka açık değildi. Toplantıların gizliliğinin klasik dönemden beri değişmeyen bir özellik olduğunu belirten Prof. Ortaylı, Türkiye'de meclis toplantılarının açık olması geleneğinin, Meclis-i Mebusan oturumlarıyla başladığını ifade etmektedir. ${ }^{57}$

Osmanlı İmparatorluğunda 1871 yılına gelindiğinde taşra yönetimi ile ilgili yeni bir düzenleme yapıldığı görülmektedir. "İdare-i Umûmiye-i Vilâyet Nizamnâmesi” ismini taşıyan bu düzenleme aslında 1864 tarihli vilayet nizamnamesini tamamlamaktadır. 1871 düzenlemesinin 62 ve 75. maddeleri Vilayet Umûm Meclisi'nin görev, yetki vs. ile ilgili idi. ${ }^{58}$ Düzenleme Vilayet Umûm Meclisi'nin görevlerini genişletmekteydi. Ancak gerek 1864 gerekse 1871 düzenlemesine göre umum meclisinin kendine has malî kaynakları ve bütçesi yoktu. Bu nedenle tam bir mahallî idare özelliğine sahip değildi fakat bir mahallî idare teşkilâtının nüvesini teşkil ediyordu. ${ }^{59}$

Kastamonu Vilayetinde de nizamname gereği Meclis-i Umûmi teşkil edilmiş ve burada azaların her birinin geldikleri sancak ve mülhak kazaların sorunlarına dair verdikleri dilekçelerin uygun bulunanları müzakere edilmişti. Müzakere neticesinde alınan kararları havi layihalar Dersaadet'e gönderilmişti. ${ }^{60} 1285$ senesi Eylül'ünde ikinci defa toplanan Kastamonu Vilayeti Meclis-i Umûmisinde muhtelif konularda müzakereler yapılmış ve bu konuda bazı kararlar alınmıştı. Alınan kararların mazbatalarının suretlerini havi layihada, aynı zamanda bir yıl evvel görüşülen konuların geçen zaman içerisinde tamamlanıp tamamlanamadığına dair malumat da verilmişti. Çalışmamızda bu layiha dışında yararlandığımız bir diğer vesika da Kastamonu Vilayetinde üçüncü defa toplanıp müzakere edilerek Şûrâ-yı Devlet'e havale olunan mazbatalardır. Biz de burada vilayet merkezinde akd olunan her iki meclis toplantısında görüşülen konuları bazı başlıklar altında vermeyi uygun gördük.

56 Nizam Önen-Cenk Reyhan, Mülkten Ülkeye Türkiye'de Taşra İdaresinin Dönüşümü (1839-1929), İletişim Yayınları, İstanbul 2011, s. 165-166.

57 Ortaylı, a.g.e., s. 90.

58 Meclis-i Umûminin bu maddeleri için bkz. Vecihi Tönük, Türkiye'de İdare Teşkilâtı, Kanaat Basım ve Ciltevi, Ankara 1945, s. 189-191.

59 Şeref Gözübüyük, Türkiye'de Mahallî İdareler, Türk ve Ortadoğu Amme İdaresi Enstitüsü Yayınları, Ankara 1967, s. 29.

60 Meclis-i Umûmi azasından Hacı Mustafa Bey ile Salim Efendi bu kararları havi layihaların merkeze tevdii memuriyetiyle Dersaadet'e gönderilmişti. BOA, A. MKT. MHM. 433/53, 20 Şevval Sene 1285 (30 Şubat 1869). 


\section{Kastamonu Vilayet Umûm Meclisinde Müzakere Edilen Hususlar}

\section{Tarımla İlgili Konular}

-Nafia Nezaretinden gönderilen 550 okkayla Amerika, Misır ve Kalecik’ten alınan 450 kıyye pamuk tohumu Safranbolu (Zağferanbolu), Tosya ve Çankırı (Kengırı)ya gönderilmiş ve Safranbolu'da 1. derece Amerika ve 2. derece Kalecik pamuğu yetiştirilmişti. Keza Tosya'da da aynı şekilde çok iyi mahsul alınmıştı. İlk vilayet meclisi müzakerelerinde görüşüldükten sonra Bursa ve Amasya'dan hükümet marifetiyle 500 bin kadar dut fidanı getirtilmiş, ayrıca varlıklı kimselerce satın alınan fidanların ahali tarafından alınarak dikilmesi ile birlikte bir sene içinde tahminen vilayet dâhiline 1 milyona yakın fidan ve 20 okka tohum girmişti.

-Bolu ve Safranbolu'da dikilmek üzere İzmir'den 150 kıyye boya tohumu talep edilmiş fakat tohumlar gelinceye kadar ekim tarihi geçtiği için bir sene evvel ekilememişti. İnebolu ve Safranbolu kazalarında dikilmek amacıyla 5.100 adet zeytin fidanı istenilmesi kararlaştırılmıştı. Bu hususta Nafıa Nezaretine gerekli talimatın verildiği merkezden vilayete bildirilmişti. Nezaretten verilen cevapta ise dikim zamanının geçmesinden dolayı bir sene sonra gönderileceği ifade edilmişti. Mecliste konu yine ele alınarak fidanların gönderilmesi hususunun nezarete tekrar bildirilmesi kararı alınmıştı.

-Karg1 Kasabasında bulunan yabani fidanların işlettirilmesi için vaki olan emr ü irade üzerine Hüdavendigâr Vilayetine, bir nefer aşı ilmini bilen bir kimse ve yeterli miktarda aşı fidanı gönderilmesine dair yazı yazılmıştı. Ancak henüz bir sonuç alınamadığından gereğinin yapılmasına dair meclisçe karar alınmıştı.

-İlk Vilayet Umûmi Meclisi kararı üzerine İnebolu Kaymakamlığından yapılan teşvikler neticesinde harir (ipek) üretiminde bir artış yaşanmış; evvelki seneye nispetle 12.000 kuruş fazla olarak öşürü ihale kılınmıştı. Yine geçen ilkbaharda ipek imalinin artırılmasına dönük olarak 50.000'den fazla dut fidanı getirtilerek diktirilmişti. İnebolu'da bağ imali arzu edildiğinden tecrübe edilmek amacıyla mevsiminde dikilmek üzere 5.000 adet bağ çubuğunun Safranbolu'dan getirtilmesi kararı alınmıştı.

-Bolu'dan verilen layihada ise, Rumeli tarafinda kullanıldığı gibi zirai alet ve edevattan hayvansız çift sürmeye mahsus yeni icat bir iki makine ile su ihracına mahsus olan burgu makinesinin getirtilmesi bazı kimseler tarafından istenilmekteydi. Ziraatın gelişmesine ve ahalinin menfaatine hizmet edecek bu makinelerin fiyatı ve muallimsiz kullanılıp kullanılamayacağı hususu mecliste kararlaştırılarak Nafia Nezaretine bildirilmişti.

-Gökçeağaç Kazasının bazı mahallerinde keten tohumu zer' olunarak (ekilerek) elde edilen mahsulattan iplik ve keten imaliyle ahalisi geçinmekte iseler de rugan-i bezir (bezir yağı) üretmek üzere birkaç adet bezirhane imali lüzumu Taşköprü Kaymakamlığından verilen layihada ifade edilmişti. İmali arzu edilen bezirhane çok fazla masraf gerektirmeyip yalnızca bir iki bin kuruşla yapılabileceğinden, gerekli teşviklerle servet sahipleri tarafından yaptırılması münasip bulunmuştu.

- Kastamonu vilayetine bağlı bazı kaymakamlıklara muhtelif yerlerden getirtilmek istenen fidan ve tohum miktarı şöyledir:

Celbi lüzumlu görünen zeytin fidanı: İnebolu Kaymakamlığı için 1.000, Daday Kaymakamlığı için 100, Safranbolu Kaymakamlığı için 100, Cide Kaymakamlığı için 2.500 adet 
Amasya'dan getirtilmesi düşünülen dut fidanı: Taşköprü Kaymakamlığı için 25.000, Daday Kaymakamlığı için 6.000, Cide Kaymakamlığı için 20.000 adet

Bolu'dan getirtilmek istenilen haşhaş tohumu: Safranbolu Kaymakamlığı için 1, Taşköprü Kaymakamlığı için 3 kıyye

Canik’ten celbine lüzum görülen kendir tohumu: Araç Kaymakamlığı için 60 kıyye

-Boyabad Kazasında pirinç mahsulü fevkalade husule gelmiş fakat verimin bir kat daha artırılması için arkların vakti zamanında temizlenmesi hususu Sinop'tan verilen layihada ifade edilmişti. Meclis-i Umûmi'de ise bu arklardan istifade eden kimselerin teşvik ettirilerek kendilerine yaptırılması kararlaştırılmıştı. ${ }^{61}$

- Çeltik arklarının temizlenmesine dair bir başka istek Meclis-i Umûmi-i Vilayet mazbatasında Kastamonu Sancağı dâhilinde bulunan Tosya Kazası ve köylerinde bulunan arklar için görülmektedir. ${ }^{62}$

-Boyabad kasabasıyla Kastamonu Sancağında vaki Tosya kazasında, Kengırı (Çankırı), Kalecik ve Çerkeş kasabalarında suyun azlığı ve yağmurun mevsiminde yetersiz yağması sebebiyle çiftçiler ümit ettikleri kadar mahsul alamadıklarından susuzluk görülen arazinin sulanması için, bedeli erbab-ı ziraatten alınmak üzere gerekli olan arkların tamiri ve yapılması kararlaştırılmıştı.

-Kastamonu Sancağına bağh İskilip, Tosya, Safranbolu, İnebolu ve Taşköprü kazalarıyla Çankırı Sancağındaki tüm kaza ve nahiyeler ile Bolu Sancağında dikilerek tarımı yapılmak istenilen fidan ve tohumlarla bunların ne zaman ve nasıl dikileceği gibi hususlarda eğitim vermek üzere erbab-ı sanattan bazı kimselerin tedarik edilerek gönderilmesi mahallerinden gönderilmiş olan layihalarda talep olunmuştu. Üstelik istihdam edilecek bu nitelikteki kimselerin maaşları da yine mahallinden karşılanacaktı. ${ }^{63}$

\section{Maarifle İlgili Hususlar;}

Vilayet Umûmi Meclisi müzakere kararlarından birisi de vilayetin kimsesiz çocukları için vilayet merkezinde yani Kastamonu' da bir ıslahhane açılmasıydı. Merkezi idarenin de müsaadesiyle Kastamonu şehrinde bulunan piyade kışla-i hümayununun bazı mahalleri düzenlenip ayrılarak sslahhane teşkil edilmişti. Islahhane Rûmî 17 Temmuz 1285 (Miladi 29 Temmuz 1869) Cuma günü Kastamonu ve çevre vilayetlerden gelen ahalinin katılımıyla Cuma namazından sonra dualarla açılmıştı ${ }^{64}$ Islahhaneye kimsesiz, fukara ve muhtaç 62 çocuk alınarak kaydedilmişti. Bunlardan 22 'si Kur'an ile hatt tahsil ederken aynı zamanda terzilik öğreniyordu. Öte yandan 25 çocuğa talim ve kitabet ile kunduracılık sanatı, 6 öğrenciye de litoğrafyacılık ilmi öğretiliyordu. Bazılarına da Dersaadet Sanayi Mektebi talebelerinden celb olunan muallim vasıtasıyla makine ile dikiş dikmek usulü gösterilmekteydi. Yine bu çocuklara Dersaadet'ten ücretle getirtilen bir marangoz ustası (Nikolaki) vasıtasıyla bu sanat öğretiliyordu. ${ }^{65}$ Müdürlüğünü Hafız Hasan Efendinin yaptığ 1slahhanede meslekî eğitim veren muallimler yanında bir adet sıbyan muallimi de ders vermekteydi. Öte yandan muallimler haricinde 1slahhanede birer kâtip, sandık emini, bevvab, odacı ve aşçı da

\footnotetext{
61 BOA, ŞD. 1639/2, 27 Receb Sene 1286 (2 Kasım 1869).

62 BOA, ŞD. 1639/13, 28 Şaban Sene 1287 (23 Kasım 1870).

63 BOA, İ. ŞD. 20/866, 18 Mart Sene 1287 (30 Mart 1871).

64 BOA, İ. DH. 597/41580, 25 Temmuz Sene 1285 (6 Ağustos 1869).

65 BOA, ŞD. 1639/1, 21 Kanunisâni Sene 1285 (2 Şubat 1870).
} 
bulunmaktayd $1 .{ }^{66}$

Vilayet Umûm Meclisi'nde ve Vilayet İdare Meclisi'nde cereyan eden müzakerelerde, açılmış olan ıslahhane yine gündeme gelmişti. Meclis tarafından hazırlanıp Şûra-yı Devlet'e havale olunan mazbatada Nafia Dairesi'nde mütalaa olunmuştu. Buradaki ifadeye göre sslahhanenin teşkili için ahali tarafından 2 yük 50.000 kuruşa yakın bir meblağ yardım yapılmıştı. Bu paranın bir kısmı talebelerin levazımına ve kışla binasının ıslahhane ittihaz olunan kısmının tanzimine sarf olunmuştu. Yarısı raddesinde bir miktar da şehir içinde sslahhaneye gelir maksadiyla oda, dükkân ve kahvehane inşa edilmişti. Ancak başlangıçta 50 olan talebe sayısı daha sonra artmış ve mevcut varidatta masrafların karşılanmasına yeterli gelmiyordu. Islahhanenin kuruluşu sırasında ahalinin yardımına başvurulmuş ve yukarıda da ifade edildiği gibi halktan da gerekli yardım güçleri nispetinde yapılmıştı. Ancak yol tesviyesi ve menafi sandıklarına sermaye tedariki gibi bazı vergiler vermekle mükellef olan halktan bu durumda tekrar yardım istemenin mümkün olmadığını düşünen vilayet idarecileri, ıslahhanenin hüsn-i idaresi ve ilerletilmesi için 100.000 ya da hiç olmazsa 60.000 kuruşun merkezden gönderilmesini talep etmişlerdi. Konu, Şûrâ-y1 Devlet' in ilgili dairesinde görüşülmüş ve ilk olarak mevcut varidat nispetinde (50 kişi) çocuk kabul olunmuş iken neden sonradan 13 çocuğun daha alındığı soruluyordu. Gelir-gider dengesi bozulup fazla masraf ihtiyar olunursa ıslahhane idaresinin ileride ıslahı çaresi bulunmaz birtakım zorluklara uğrayacağının belli olduğu bu nedenle de fazla ve daimi varidat bulunmadıkça talebelerin sayısının artırılmayıp "oluruyla" idare edilmesi tembih ediliyordu. Öte yandan senelik masrafları ve yaptırılan akar ve oradan senede ne miktar akçe hâsıl olduğunun vs. mazbatada tafsilatıyla belirtilmediğinden bunların ayrıntılı bir şekilde açıklanması istenilmekteydi. Ancak bunlara karşılık böyle hayırlı bir eserin cüzi bir şey için "tatilinin" devletin şanına muvafık olamayacağından talep edilen paranın verilmesi Şûrâ-yı Devletçe uygun bulunmuş ve gereğinin yapılmasının Maliye Nezaretine tavsiye ve havalesine karar verilmişti. ${ }^{67}$

Vilayet Umûmi Meclisinde eğitime dair müzakere edilen hususlardan birisi de mekteplerin ihtiyacına dönük taleplerdi. İnebolu Kaymakamlığı Rüşdiye Mektebinin tamamlanmasından ötürü ihtiyaç duyulan bir adet muallim talebi merkeze iletilmiş ve keyfiyet Şûra-yı Devletten Maarif Nezaretine iletilmişti. ${ }^{68}$

Kastamonu Meclisi Umûmisinde maarife dair bir başka talep de Sinop Sancağı mülhakatından İstefan kazasından idi. Kaza merkezi olan Ayancık İskelesinde inşa olunan camii bitişiğinde, varlıklı hayırsever kimseler tarafından yapılacak yardımlarla bir Rüşdiye Mektebi yaptırılması ve bu mektep için de maaşı devlet tarafından verilmek üzere bir muallim tayini kararı alınmıştı. ${ }^{69}$ Yine Sinop Sancağına mülhak Boyabad ve Kastamonu'da İnebolu ve kazalarında servet sahibi kimselerin yardımlarıyla birer rüşdiye mektebi açılırken bazı binaları eskimiş sıbyan mekteplerinde de tadilat yapılmıştı. Bartın'da da yanmış olan çarşı civarında bulunan büyük bir sıbyan mektebi yine ahalinin yardımıyla kasabanın münasip bir mahalline nakledilmişti. Mecliste bunlara ilave olarak 30'dan fazla mektebin daha inşa edilmesi kararı alınmıştı. ${ }^{70}$

\footnotetext{
66 BOA, ŞD. 1638/38, 17 Şevval Sene 1286 (20 Ocak 1870)

67 BOA, İ. ŞD. 19/781, 25 Mart Sene 1286 (6 Nisan 1870).

68 BOA, ŞD. 1639/4, 21 Muharrem Sene 1287 (23 Nisan 1870).

69 BOA, İ. ŞD. 21/876, 27 Mart Sene 1287 (8 Nisan 1871).

70 BOA, ŞD. 1639/1, 21 Kanunisâni Sene 1285 (2 Şubat 1870).
} 
Bolu'dan gelen layihada belirtilen husus ise oldukça dikkat çekicidir. Layihaya göre Bartın ahalisi Ereğli kömür maden-i hümayununa merbut (bağlı) ve fazla amele vermeye mecburdular. Bazı ocakların alçak olması hasebiyle madenciler tarafından "büyük adem" yani yetişkinler çalıştırılmayarak henüz sıbyan mektebinde olması elzem olan küçük çocuklar istihdam ediliyordu. Mektebe gidemeyen çocuklar "zulmet-i cehl” içinde yani cehaletin karanlığında kalıp dini ilimlerden ve umumiyetle okuma-yazmadan bihaber kalıyorlardı. Bundan sonra ahalinin 60 yaşından yukarı olanlarla 15 yaşından aşağı bulunan çocukların amelelikten muaf tutulmaları isteniyordu. Ayrıca nüfusa nispetle yetersiz olan sıbyan mekteplerinin sayısının artırılması da özellikle isteniyordu. Merkezi idare vilayetin isteklerini uygun görmüş ve gereken müsaade verilmiş, sıbyan mekteplerine dair talep için de Maarif Nezaretine iletilmesi uygun görülmüştü. ${ }^{71}$

\section{Nafia İșleri İle İlgili Hususlar}

Kastamonu Vilayeti Umûm Meclisinin teşkil olunan ve 33 gün süren ikinci toplantısında kazalardan gelip meclise sunulan layihalara bakıldığında, en fazla gündeme getirilen konuların başında bayındırlıkla alakalı konular görülmektedir. İlk Vilayet Umûm Meclisi'nde de gündeme getirilmiş olan Safranbolu'dan Amasra'ya kadar olan yolun bozukluğu hasebiyle tanzim ve tesviyesine dair karar alınmıştı. ${ }^{72}$ Nafia Nezaretiyle cereyan eden müzakereler neticesinde bir mühendis ve bir kondöktor tayin edilerek gönderilmişti. Mühendis ve kondöktorun gelmesiyle söz edilen yolun haritası yapılmış ve gerekli işçiler çeşitli mahallerden tertip edilmişti. Fakat Bartın'a su getirtilmesi için yapılması lüzumlu olan arkın kazılmasına da başlanmıştı. Arkın uzaklığı ve mevkii nedeniyle büyük bir iş olduğundan bir mühendisin bu iki işe birden tam olarak nezaret edemeyeceği gibi işçilerinde yetersiz olacağından önceliğin ark yapımına verilmesi kararlaştırılmıştı. Mezkûr yolun yapımına ise ilkbahar sonunda başlanılması düşünülmüştü.

Boyabad kasabasında hane lağımlarının açıkta olması ve sokağa akmasından dolayı hem umumi sağlığa hem de tanzimat-1 belediyeye mugayir olduğu bildirilmişti. Yine kasaba içinde bulunan çarşı ve pazar kaldırımlarının tesviye ve tanzimiyle beraber yangından muhafazası için dükkânların saçaklarının da "Ebniye Nizamına" göre fazlalıklarının kesilerek muntazam bir hale getirilmesi layihada arz ediliyordu. Meclis-i Umûmi ise bu gibi konuların Belediye Meclisi marifetiyle yapılabileceğini oysa Boyabad Kazasında henüz Meclis-i Beledi teşkil olunmadığından evvela belediye meclisi teşkil edilerek onun marifetiyle bu türden icraatın yapılmasını uygun görmüştü.

Dönemin en mühim sorunlarından birisi de hiç şüphesiz yangındı. Hane yapımında çoğunlukla ahşap malzeme kullanılması yangının verdiği zararı daha da büyütüyordu. Ahalinin yangından korunması zımnında Bolu ile Bartın, Ereğli, Gerede ve Göynük kaymakamlıkları için masrafları mahalleri belediye sandığından karşılanmak üzere dört takım yangın tulumbası isteniyordu. Meclis talebi gerekli ve yerinde bularak ilgili makama bildirilmesine kararı vermişti. ${ }^{73}$

71 BOA, ŞD. 1639/2, 27 Receb Sene 1286 (2 Kasım 1869).

72 Prof. İlber Ortaylı’ya göre Kastamonu Vilayetinde bu dönemde bazı limanlar (iskeleler) önemini kaybederken bazıları önem kazanmıştı. Örnek olarak da Sinop Limanı'nın önemini yitirmesi ve Safranbolu-Bartın-Amasra ekseninin de zamanla daha önemli hale gelmesini vermiştir. Bunun sebebini ise yalnızca İstanbul ile değil aynı zamanda Çarlık Rusyasının limanları ile olan ilişkilerin artışına bağlamaktadır. İlber Ortaylı, “19. Yüzyılda Kastamonu Vilayetindeki Yapısal Değişim Üzerine”, A. Ü. Siyasal Bilgiler Fakültesi Basın Yayın Yüksekokulu Yıllığından Ayrı Basım, Ankara 1977, s. 301-302. 
Meclisin gündemine alınan konulara bakıldığında yapılan talepler arasında mülhak kazalarda ticaretin canlanmasına dönük istekler de dikkat çekmektedir. Bu taleplerden birisi kazalarda küşad olunan pazar ve panayırlara dair olanlardır. Örneğin Taşköprü kazası dâhilinde ikâme olunan pazarın kasım ayından sonra daimi surette açık kalması ve buraya lüzumu kadar dükkân yaptırılması mahallinden talep olunmuştu. Yine Taşköprü kazasında Gökçeağaç isimli mevkii de her sene üç ay ikame olunan Kurum Pazarının artık her hafta kurulmak üzere Sağır Han isimli yere nakli ile bu hanın tamiri ve burada lüzumu kadar dükkânın ıslahhane tarafından yaptırılması istenilmekteydi.

Vilayette ticaretin ilerletilmesine dönük olarak Çerkeş kazası ahalisinden talep edenlere iplik alacası nesc (dokuma) ve imalini ve dibagat (deriyi kullanılır hale getirme) sanatını talim için birer usta tayini mahallinden bildiriliyordu. ${ }^{74}$ Bolu'da ise aba dokuma ve üretimi için Filibe'den muallim talep olunmuştu ancak orada bulunan muallimlerin kadın olmaları nedeniyle bu isteğe rağbet etmedikleri bildirilmişti. Daha sonra ise Balıkesir'den getirtilmek düşüncesiyle Hüdavendigâr Vilayetine müracaat edilmiş fakat gelecek muallimin maaşının makul bulunmaması nedeniyle vazgeçilmişti. Çankırı Sancağında ise sancak dâhilinde bulunan Kalecik Kaymakamlı̆̆ında yetiştirilen kozadan ipek yapılmak üzere Amasya'dan gönderilen muallim ise ahaliye ipek yapım usulünü talim etmekteydi.

Vilayet Umûmi Meclisi müzakerelerinde en fazla müzakere edilen hususlardan birisi de yol, köprü yapımı ve onarımı ile ilgiliydi. Bu yolların bazılarının yapımı ya da onarımı da yine ticaret ile doğrudan bağlantılıydı. Bolu Kazasıyla mülhakatından olan nahiyelerin mahsulatının dışarıya taşınmasında önemli bir yeri olacak iskelenin yolu olmaması "servet" ve "mamuriyetin" ilerlemeyerek geri kalmasına müstakil bir sebep olarak görülmüsstü. Bu nedenden ötürü Bolu'dan sahile olan üç yoldan (İzmid, Akçaşehir ve Ereğli iskelesi) Ereğli iskelesinin Bolu'ya yakınlığı cihetiyle bu yolun tesviyesinin ticaretin gelişmesi ve bunun ahalice birçok menfaati mucib olacağı bildirilmişti. Merkezi idarece talep yerinde bulunmuş ve merkez-i vilayet Beledi Meclisi mühendisliğine tayin edilen Salih Efendi'nin, Erzurum'dan vilayete varmasından sonra kendisi tarafından yolun keşif ve haritasının tanzim ettirilmesine karar verilmişti. ${ }^{75}$ Kastamonu vilayeti dâhilinde başlıca üç yol tesviye olunmaktaydı. Bunların biri İnebolu'dan Kastamonu'ya ikincisi Kastamonu'dan Çankırı'ya öbürü de Sinop'tan Hacı Hamza'ya ulaşan yol idi. 1869 yılı Nisan ayından Kasım ayına kadar geçen yedi ay süresinde İnebolu yolunun 14.307 metrelik kısmının yapımı tamamlanmıştı. Yine bu mevkii de 11 adet büyük ahşap köprü, 926 metre duvar, 26 adet kârgir ve ahşap lağım inşa olunmuştu. Çankırı yolunda da "tam ve yarım genişliğinde" toplam 8.190 metrelik kısmı toprak olarak tesviye edilirken 39 mahalde de köprü inşa edilmişti. Sinop yolunun tanzim olunan kısmı 9.434 metreye ulaşmıştı. Bu üç yolun toplam 31.996 metre uzunluğundaki düzenleme ile 59 köprü, duvar ve lağım yapılmıştı. Bu yollardan İnebolu yolu kış günlerinde kapanıp geliş gidişe engel olmaktaydı. Yolun bozuk olan kısımları ile dere içleri olmak hasebiyle onarımı da çok zordu. Arabaya yük hayvanatı bile 3-5 mahalde aktarma yapmadıkça geçemiyor ve havaların müsait olmadığı zamanlar yol uzun müddet kapanıp kalmaktaydı. İnebolu yolunun bozuk, harap olan kısımlarının, özellikle yük arabalarının geçebileceği bir hale getirilmesi için bir sene evvel çalışma yapılmıştı. Bir yıl sonra mühendislerin de ifadelerine göre İnebolu ve Çankırı yolunun birleşeceği ve Çankırı yolunda da araba geçişine mani yerlerin onarımıyla artık bu sorunun ortadan kalkacağı tasavvur olunmuştu. Öte yandan Tuna vilayetindeki başarılı uygulamalar tüm

74 BOA, İ. ŞD. 18/773, 15 Nisan Sene 1286 (27 Nisan 1870).

75 BOA, ŞD. 1639/2, 27 Receb Sene 1286 (2 Kasım 1869). 
Osmanlı vilayetlerine örnek oluyordu. Tuna vilayetinde olduğu gibi Kastamonu'da da posta arabaları işletilmek üzere büyük bir kumpanya kurulması tasarlanmıştı. İlk olarak yolcu nakline mahsus 8 arabanın kaç kuruşa satın alınabileceği ve ne kadar masrafla getirtilebileceği gibi bazı hususlara dair Tuna vilayeti valiliğine resmî yazı yazılarak bilgi alınması Meclis-i Umûmi'de kararlaştırılmıştı. ${ }^{76}$

Kastamonu Vilayet Umûm Meclisinde müzakereye konulan isteklerden bazıları da hükümet konağı, hapishaneler, hastane binaları gibi kamu binalarının yapımı, onarımı ya da ilaveler yapılmasına dair isteklerdi. Bu binaların yanında vilayete bağlı kimi sancak ve kazalarda bulunan camilerin eksiklerinin giderilmesi ile ilgili talepler de vardı. Bu isteklerden başka, kasabada pis kokuların önlenip sağlık ve temizliğin muhafazasına dönük selhhane (mezbaha) yapılması gibi istekler de olabiliyordu. Bu hususlarda meclis gündemine alınan taleplere birkaç örnek vermek yerinde olacaktır. Çerkeş kasabasında mahalle aralarında kesilen koyunlardan hâsıl olan pis kokuların temiz havayı kirlettiğinden 800 kuruş masrafla belediye tarafından bir selhhane yapılabileceği ve bu selhhaneden temin edilecek 150 kuruş kira bedelinin de yine belediyeye irat olarak kaydedilebileceği bildiriliyordu. Şura-yı Devlet'te inşaat için ifade edilen meblağ uygun bulunmuş, bu miktarı geçmemek ve belediyeye irat olarak kaydolmak koşuluyla yapımına izin verilmişti. ${ }^{77}$ Boyabad kazasında servet sahibi ahalinin yardımlarıyla kaymakamlık merkezi olan Boyabad kasabasında 14 odalı bir hükümet konağıyla hemen bitişiğinde 3 odalı telgrafhane yapılmıştı. İstefan kaymakamlığının merkezi olan Ayancık İskelesi’nde de yine varlıklı kimseler tarafından bir hükümet konağı inşası tamamlanmıştı. Yine meclis-i umumi kararlarından Tosya Kaymakamlığı hükümet dairesi içinde, servet sahibi ahalinin katkısıyla bir zabtiye koğuşu, bir süvari ahırı yapılmıştı. Ayrıca vilayet merkez hapishanesine daire-i belediyeden mahpuslar için yeni bir hastane ve birkaç adet zabitan odası ilave edilmişti. ${ }^{78}$ Safranbolu kazası nahiyelerinden Eflani ve Ulus nahiyelerinde birer hükümet konağıyla Boyabad kasabasında metfun şeyhlerden Şeyh Mustafa Efendi Hazretlerinin türbesi yanında masrafları ashab-1 hayır tarafından yapılacak iane ile bir türbedar dairesi inşa olunması istenilmekteydi. Masrafı beledi hasılatından karşılanmak üzere Çankırı hapishanelerinin tamiri de alınan benzer kararlardandı. Az evvel belirtildiği üzere mecliste sıkça görülen isteklerden bazıları camilerle ilgiliydi. Örneğin Sinob Sancağına bağlı Boyabad kasabasında yıkılmaya yüz tutmuş olan Kum Mescid-i Şerifi'nin tamiri için ahalinin ianesi hâricinde sarfina lüzum görünen 5.000 kuruşun Evkaf-ı Hümayun hazinesinden verilmesi talep ediliyordu. Kastamonu Sancağı dâhilinde bulunan Cide ve Araç kazaları merkezlerinde bulunan camilerin tamiri yine bu kabilden taleplerdendi. Şûra-yı Devlette meclisin bu istekleri görüşülmüş ve halktan toplanacak yardımlarla ilgili, kimseden rızası dışında zorla para alınmaması ve gerekli defterlerin merkeze gönderildikten sonra Evkaf ve Maliye Nezaretleriyle yapılacak yazışmalar neticesinin vilayete tebliğ edileceği şeklinde karar verilmişti.

Son olarak vilayet umûmi meclislerine verilen görevlerden birisi de vilayete bağlı liva, kaza ve köylerde alınan vergilerin değiștirilmesi ya da yeni vergilerin konulması ile ilgilidir. Kastamonu Vilayeti Umûmi Meclisinde de vergi meselesine dair bazı görüşmeler yapıldığını görmekteyiz. $\mathrm{Bu}$ hususta mecliste İnebolu köylerinin vergilerinin tadili için vilayet dâhilinde bulunan tahrir

77 BOA, İ. ŞD. 20/866, 18 Mart Sene 1287 (30 Mart 1871).

78 BOA, ŞD. 1639/1, 21 Kanunisâni Sene 1285 (2 Şubat 1870). 
memurlarının bölgeye gönderilmesi kararlaştırılmıştı. ${ }^{79}$

\section{Sonuç}

1864 Vilayet Nizamnamesi ile birlikte Osmanlı İmparatorluğu'nda uzun süredir uygulanan eyalet sisteminden tedricen vazgeçilerek vilayet sistemine geçilmişti. İlk olarak Tuna vilayetinde Midhat Paşanın valiliğinde uygulanan sistemin başarılı neticeleri görülmesiyle birlikte, imparatorluğun farklı bölgelerinde de hayata geçirilmeye başlanmıştı. Sistemin tatbik edildiği yerlerden birisi de bu çalışmanın konusu olan Kastamonu idi. Kastamonu Vilayetinin kurulmasıyla birlikte kente yeni memurlar tayin olunmuş, yerel düzeyde yeni daireler teşkil edilmişti. Yeni düzenlemenin getirdiği en mühim yeniliklerden birisi de taşra idaresinde yer almaya başlayan Vilayet Umûmi Meclisleri idi.

Vilayet Umûmi Meclisleri, vilayetlere bağlı livalardan seçilerek gelen üyelerden (Müslim ve gayrimüslim) teşkil olunmaktaydı. Vilayet merkezinde ve valinin başkanlığında toplanan meclisin toplantı süresi 40 günü geçmeyecekti. Vilayete mülhak livalardan gelen azalar, geldikleri yöre ile ilgili çeşitli taleplerin olduğu dilekçeleri valiye sunuyorlardı. Ancak gündeme alınacak konular vali tarafından belirlenmekteydi. Mecliste müzakere edilip alınan kararlar merkeze gönderiliyordu, zira meclisin karar alma yetkisi yoktu. İlgili nezaret ve komisyonlara gönderilen talep ve öneriler, merkezi idare tarafından onaylanabilir, reddedilebilir ya da kısmen değiştirilerek uygulanmasına onay verilebilirdi. Bu durum ise Vilayet Umûmi Meclislerini birer danışma meclisi hüviyetine sokuyordu. Karar alıp uygulama yetkisinin bulunmaması, tüzel kişiliğinin olmaması gibi birtakım olumsuz niteliklerine rağmen umumi meclislerin 19. asırda Osmanlı İmparatorluğu'nda taşra idaresi ile alakalı yapılan birtakım düzenlemeler içerisindeki önemini göz ardı edemeyiz. Kastamonu vilayetinin kuruluşu ve akabinde teşkil olunan Vilayet Umûmi Meclisinin faaliyetleriyle bu önemi ortaya koymaya çalıştık.

Kastamonu Vilayet Umûmi Meclisi, nizamname gereği gayrimüslim ve Müslim azaların seçimiyle vilayet merkezinde senede bir defa olmak üzere toplanmıştı. Bu çalışmada meclisin ilk 3-4 yıllık icraatlarından bazı örneklerle bu meclislerin Osmanlı idare tarihindeki önemini ortaya koymaya çalıştık. Umûmi Meclise verilen görevlere bakıldığında bunların yol, köprü, çeşme ya da cami, mescit gibi bazı dini yapıların bakım, yapım ve onarımı, vilayette tarım ve ticaretin geliştirilmesine yönelik çalışmalar, halktan alınan veyahut alınacak vergilerle ilgili düzenlemeler şeklinde sıralayabiliriz. Kastamonu Vilayet Umûmi Meclisinde yapılan görüşmelere bakıldığında vilayete bağlı çeşitli kazalardan bu konularda birçok talep ve öneriler görülmektedir. Özellikle tarımın geliştirilmesine dair yapılan çalışmalar ile yol yapımına dair icraatlar hemen göze çarpmaktadır. Alınan kararlara bakıldığında küçük çocukların maden ocaklarında çalıştırılmayıp okula gönderilmeleri gibi dikkate değer önemli kararlar olurken, yangınlara karşı birkaç tulumba alınması ya da aşı yapmayı bilen bir kimsenin getirtilmesi gibi basit konularda olabiliyordu. Meclisin görevlerine bakıldığında bunun da sınırının tam olarak belirlenmediği söylenebilir çünkü bazı talep ve öneriler vali tarafından ya da merkezi idare tarafından belediyenin görev ve yetki alanına girdiği gerekçesiyle reddedilmekteydi. Osmanlı İmparatorluğu'nun diğer vilayetlerinden de benzer isteklerin gelmesi ile imparatorluğun bu dönemdeki malî yapısı birlikte düşünüldüğünde, meclislerin taleplerine müspet cevap vermenin ne kadar güç olacağı çok açıktır. Ancak az evvel de belirttiğimiz gibi merkezi idarenin talepleri karşılayacak maddi imkânı ve personeli de yoktu. 
Halkın katkısıyla yapılacak işler çoğunlukla onaylanmış ve işlerin bu şekilde yapılmaya çalışılması da teşvik edilmişti. Prof. İlber Ortaylı bu meclisleri "ricacı kuruluşlar" olarak nitelendirse de meclislerin kendisine verilen görevleri, yetkisi çerçevesinde iyi niyetle yerine getirmeye çalıştı̆̆ görülmektedir. Kastamonu Umûmi Meclisi kararlarının Şûrâ-yı Devlette görüşülüp ilgili nezaretlere gönderilmesi de meclislere verilen önemi göstermektedir. Üstelik taşrada halk, sorunlarını umûmi meclisler vasıtasıyla merkezi idareye iletme imkânına kavuşmuştu.

\section{Kaynakça}

\section{T.C Cumhurbaşkanlığı Devlet Arşivleri Başkanlığı (BOA)}

Sadâret Mektûbî Kalemi, Mühimme Kalemi (Odası) Belgeleri (A. MKT. MHM):

A. MKT. MHM. 378/88, 9 Mart Sene 1282 (20 Mart 1867); A. MKT. MHM. 387/41, 11 Rebiülevvel Sene 1284 (13 Temmuz 1867); A. MKT. MHM. 388/42, 13 Temmuz Sene 1283 (25 Temmuz 1867); A. MKT. MHM. 394/53, 26 Teşrinievvel Sene 1283 (7 Kasım 1867); A. MKT. MHM. 396/27, 17 Şevval Sene 1284 (11 Şubat 1868); A. MKT. MHM. 396/54, 21 Şaban Sene 1284 (18 Aralık 1867); A. MKT. MHM. 397/97, 12 Ramazan Sene 1284 (7 Ocak 1868); A. MKT. MHM. 399/87, 28 Kanunievvel Sene 1283 (9 Ocak 1868); A. MKT. MHM. 433/53, 20 Şevval Sene 1285 (30 Şubat 1869).

Cevdet Dâhiliye (C. DH):

C. DH. 107/5304

İrâde-Dâhiliye (İ. DH):

İ. DH. 585/40764, 29 Ramazan Sene 1285 (13 Ocak 1869); İ. DH. 597/41580, 25 Temmuz Sene 1285 (6 Ağustos 1869).

İrâde-Meclis-i Mahsus (İ. MMS):

İ.MMS. 133/5692, 29 Muharrem Sene 1284 (2 Haziran 1867)

İrâde-Meclis-i Vâlâ (İ. MVL):

İ. MVL. 575/25823; İ. MVL. 580/2652, 5 Receb Sene 1284 (2 Kasim 1867); İ. MVL. 582/26152, 17 Ağustos Sene 1283 (29 Ağustos 1867).

İrâde-Şûrâ-yı Devlet (İ. ŞD):

İ. ŞD. 7/349, 1 Rebiülevvel Sene 1285 (22 Haziran 1868); İ. ŞD. 18/773, 15 Nisan Sene 1286 (27 Nisan 1870); İ. ŞD. 19/781, 25 Mart Sene 1286 (6 Nisan 1870); İ. ŞD. 20/866, 18 Mart Sene 1287 (30 Mart 1871); İ. ŞD. 21/876, 27 Mart Sene 1287 (8 Nisan 1871).

Meclis-i Vükelâ Mazbataları (MVL):

MVL. 739/44, 21 Teşrinievvel Sene 1283 (2 Kasım 1867); MVL. 740/41, 16 Teşrinievvel Sene 1283 (28 Ekim 1867).

Şûrâ-yı Devlet Belgeleri (ŞD):

ŞD. 1638/2, 17 Nisan Sene 1284 (29 Nisan 1868); ŞD. 1638/38, 17 Şevval Sene 1286 (20 Ocak 1870); ŞD. 1639/1, 21 Kanunisâni Sene 1285 (2 Şubat 1870); ŞD. 1639/2, 27 Receb Sene 1286 (2 Kasım 1869); ŞD. 1639/4, 21 Muharrem Sene 1287 (23 Nisan 1870); ŞD. 1639/13, 28 
Şaban Sene 1287 (23 Kasım 1870).

Matbu Vesikalar ve Süreli Yayınlar

Düstur, 1. Tertib, Cilt 1

Salnâme-i Devlet-i Aliyye-i Osmaniyye, Def'a 1, Sene 1263; Salnâme-i Devlet-i Aliyye-i Osmaniyye, Def'a 5, Sene 1267

Salnâme-i Vilâyet-i Kastamonu, Def’a 1, Sene 1286

Takvim-i Vekayi, 16 Mart 1867 (10 Zilkade Sene 1283), Nr. 875; 4 Ekim 1867 (5 Cûmâdelâhire Sene 1284), Nr. 894; 8 Ekim 1867 (9 Cûmâdel-âhire Sene 1284), Nr. 895

\section{Araştırma Eserleri}

AKBAL, Fazıla (1951), “1831 Tarihinde Osmanlı İmparatorluğu’nda İdarî Taksimat ve Nüfus”, TTK, Belleten, Cilt XV, Say1 60, Ekim 1951, s. 617-628.

BAYKARA, Tuncer, Anadolu'nun Tarihî Coğrafyasına Giriș I Anadolu'nun İdarî Taksimatı, Türk Kültürünü Araştırma Enstitüsü Yay., Ankara 1988.

ÇADIRCI, Musa, “Anadolu'da Redif Askeri Teşkilâtının kuruluşu”, Cilt 8, Sayı 14, Mayıs 1963, s. 63-75. Ankara 1991.

, Tanzimat Döneminde Anadolu Kentlerinin Sosyal ve Ekonomik Yapıları, TTK, Eylül 1993, s. 3-12.

, “Osmanlı Döneminde Yerel Meclisler”, Çağdaş Yerel Yönetimler, Cilt 2, Sayı 5, , “Tanzimat”, Osmanlı, Cilt 6, Yeni Türkiye Yayınları, Ankara, 1999, s. 183-198.

DAVISON, Roderic, Osmanlı İmparatorluğu'nda Reform, 1856-1876, Çev. Osman Akınhay, Agora Kitaplı̆̆ı, İstanbul 2005.

GÖYÜNÇ, Nejat, Osmanlı Devleti'nde Taşra Teşkilâtı (Tanzimat'a Kadar), Osmanlı, Cilt 6, Yeni Türkiye Yayınları, Ankara 1999, s. 77-88.

GÖZÜBÜYÜK, Şeref, Türkiye'de Mahallî İdareler, Türk ve Ortadoğu Amme İdaresi Enstitüsü Yayınları, Ankara 1967.

INALCIK, Halil, “Eyalet”, TDV İslâm Ansiklopedisi, Cilt 11, İstanbul 1995, s. 548-550.

IZZGÖER, Ahmet Zeki, “Osmanlı Salnâmelerinin Şehir Tarihi Bakımından Önemi”, Türkiye Araştırmaları Literatür Dergisi, Cilt 3, Sayı 6, 2005, s. 539-552.

KARAL, Enver Ziya, Osmanlı Tarihi, Cilt 7, TTK Ankara 2003.

, Osmanlı Tarihi, Cilt 6, TTK Ankara 2007.

, Osmanlı Tarihi, Cilt 5, TTK, Ankara 2007.

KILIÇ, Orhan, 18. Yüzyılın İlk Yarısında Osmanlı Devleti’nin İdarî Taksimatı Eyalet ve Sancak Tevcihatı, Elazı̆̆ 1997.

KILIÇ, Selda Kaya, Tanzimat'tan Cumhuriyet'e Türkiye'de İl Yönetimi, Ankara Üniversitesi, 
Sosyal Bilimler Enstitüsü, Tarih Anabilim Dalı, Doktora Tezi, Ankara 1995.

LEWIS, Bernard, Modern Türkiye'nin Doğuşu, TTK, Ankara 1993.

ORTAYLI, İlber, “19. Yüzyılda Kastamonu Vilayetindeki Yapısal Değişim Üzerine”, A. Ü. Siyasal Bilgiler Fakültesi Basın Yayın Yüksekokulu Yıllığından Ayrı Basım, Ankara 1977, s. 301-307.

, Tanzimat Devrinde Osmanlı Mahallî İdareleri (1840-1880), TTK Ankara 2000.

ÖNEN, Nizam ve REYHAN Cenk, Mülkten Ülkeye Türkiye'de Taşra İdaresinin Dönüşümü (1839-1929), İletişim Yayınları, İstanbul 2011.

PAKALIN, Mehmet Zeki, Osmanlı Tarih Deyimleri ve Terimleri Sözlüğü II, İstanbul 1993.

REYHAN, Cenk, "Cebel-i Lübnan Vilâyet Nizamnamesi”, Memleket Siyaset Yönetim, 2006/1, s. 171-181.

SENCER, Muzaffer, Türkiye’nin Yönetim Yapısı, Alan Yayıncılı, İstanbul 1986.

SEYITTDANLIOĞLU, Mehmet, "Yerel Yönetim Metinleri III: Tuna Vilayeti Nizamnamesi”, Çağdaş Yerel Yönetimler, Cilt 5, Sayı 2, Mart 1996, s. 67-81.

ŞAHİN, İlhan, "Kastamonu”, TDV İslam Ansiklopedisi, Cilt 24, İstanbul 2001, s. 585-588.

TÖNÜK, Vecihi, Türkiye’de İdare Teşkilâtı, Kanaat Basım ve Ciltevi, Ankara 1945.

TURAL, Erkan, “1861 Hersek İsyanı, 1863 Eyalet Teftişleri ve 1864 Vilayet Nizamnamesi”, Çağdaş Yerel Yönetimler, Cilt 13, Say1 2, Nisan 2004, s. 93-123.

, "Minyatür Bir Tanzimat Ülkesi: Lübnan ve 1861 Lübnan Vilayet Nizamnamesi", Çăgdaş Yerel Yönetimler, Cilt 14, Sayı 2, Nisan 2005, s. 65-91.

TURAL, Erkal ve ÇAPAR, Selim, 1864 Vilayet Nizamnamesi, Türkiye ve Orta-Doğu Amme İdaresi Enstitüsü, Ankara 2015.

YAMAN, Talât Mümtaz, Osmanlı İmparatorluğu Mülkî İdaresinde Avrupalılaşma Hakkında Bir Kalem Tecrübesi, İstanbul 1940. 